\title{
Framåtsyftande bedömning i tidig läsundervisning - Teori och praktik
}

Ulrika B. Andersson 



\title{
Framåtsyftande bedömning i tidig läsundervisning
}

\author{
- Teori och praktik
}

\author{
Ulrika B. Andersson
}

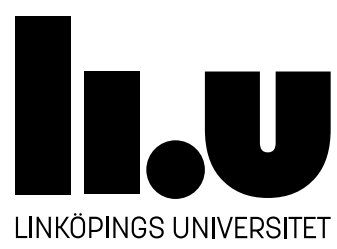

Linköping Studies in Behavioural Science No. 229 Utbildningsvetenskap

Linköping 2021 
Linköping Studies in Behavioural Science • No. 229

Distribueras av:

Institutionen för Beteendevetenskap och Lärande Linköpings universitet

58183 Linköping

Ulrika B. Andersson

Framåtsyftande bedömning $\mathrm{i}$ tidig läsundervisning -Teori och praktik

Upplaga 1:1

ISBN 978-91-7929-646-9

ISSN 1654-2029

CUlrika B. Andersson

Institutionen för Beteendevetenskap och Lärande, 2021

$($ (c) EY-No Detta verk är licensierat under en Creative Commons ErkännandeIckeKommersiell 4.0 Internationell Licens.

https://creativecommons.org/licenses/by-nc/4.0/deed.sv

Tryckeri: LiU-tryck, Linköping 2021 


\section{Förord}

Mitt avhandlingsarbete kan liknas vid en skogstur med en utgångspunkt och ett ungefärligt mål. På kartbladet över skogsturen fanns flera möjliga stigar mot målet. I början av turen förde mitt forskningsintresse mig in på en stig med dubbla spår som var intressant. En bit in på den nya stigen dök ännu en möjlig väg upp. Det innebar att två parallella spår blev nästan tre. Det var allt lite rörigt, även om det var intressant och spännande. Jag lämnade det tredje spåret och höll mig till det parallella spåret, det vill säga tidig läsning och framåtsyftande bedömning. Att följa två spår i en blandning av känd och okänd natur har inneburit en utmaning. Stigen har innehållit allt ifrån branta uppförsbackar (ja fjälltoppar nästan) och sega motlut, till enklare stigar med ett och annat litet nedförslut. Det ska sägas att jag redan från början och under hela tiden har haft gott stöd från flera olika håll. Det har varit mycket betydelsefullt och har på olika sätt bidragit till att jag kan skriva dessa rader nu.

Mitt första och största tack riktar jag till min huvudhandledare Stefan Gustafson. Tack för att du så frikostigt delat med dig av ett fantastiskt kunnande inom forskningsfälten läsning och bedömning. Tack även för gott stöd och tålamod.

Min uppriktiga tacksamhet riktar jag också till mina två bihandledare, Håkan Löfgren och Linda Fälth som båda två har bidragit med värdefull kunskap, stöd och inspirerande tankar inom sina respektive fält.

Tack Stefan och Håkan för att ni med ett öppet och nyfiket förhållningssätt stöttat valet av kompassriktning som inkluderade tidig läsundervisning och framåtsyftande bedömning.

Tack också till Åsa Elwér som var min biträdande handledare alldeles i början, innan jag svängde in på vägen med dubbla spår.

Varmt tack också till mina medförfattare för gott och värdefullt samarbete. Stort tack till Sofia Norén, verksamhetschef och Sara Anvarsson, projektledare, för stiftelsen LegiLexi, för samarbete som möjliggjort datainsamling för två av avhandlingens studier. Jag vill också rikta mitt varma tack till de lärare som deltagit $\mathrm{i}$ avhandlingens forskningsprojekt.

Stort tack till Christian Lundahl, Örebro universitet för värdefulla råd vid mitt 60\% seminarium och till Åsa Hirsh, Göteborgs universitet, för en bra diskussion och framåtsyftande råd vid mitt $90 \%$ seminarium. Tack även till läsgruppen, Robert Thornberg och Per Andersson, för god guidning och värdefulla kommentarer inför det avslutande arbetet.

Tack till medlemmarna i FoB (Forskning om Bedömning) och Berättelseforskningsgruppen vid IBL, Linköpings universitet, för intressanta och värdefulla diskussioner.

Det finns många som på olika sätt har bidragit till att forma min upplevelse av att vara doktorand. Tack, kollegor på lärarutbildningen doktorander och administratörer tillhörande Avdelningen Pedagogik och Didaktik, för fint samarbete, stöd och värdefulla möten. Stort tack till 
doktoranderna; Magnus Jansson, Anja Gramner, Tobias Jansson, Cecilia Björkhammar, Tove Mattson, Sofia Boo, Christina Aminoff och Elisabeth Tenglet för korrekturläsning av kappamanuset. Varmt tack till Magnus Bengtsson för läsning och intressanta diskussioner. Hjärtligt tack till Kicki Olsson och Per Olsson för påminnelser om att det finns annat att göra än att skriva en avhandling.

Sist men inte minst vill jag tacka min familj; mina föräldrar och syskon, tack för att ni varit så där lagom intresserade av avhandlingen och mer av att umgås och till exempel ta en fika i skogen. Tack Anna, Ebba, Lisa och Jens. Det finns så mycket roligt i världen och det påminner ni mig om. Tack också till min kära make, du håller ställningarna i alla väder och gör allt, utom att läsa avhandlingstext. Det hade varit mycket svårare att skriva en avhandling utan dig!

Ulrika Andersson, Velendebo, april 2021 


\section{Innehåll}

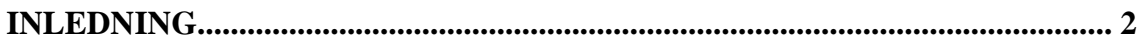

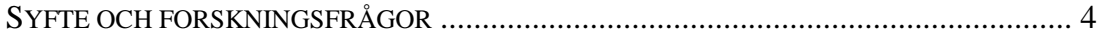

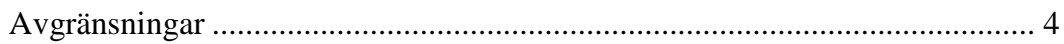

TEORI OCH TIDIGARE FORSKNING_.......................................................... 5

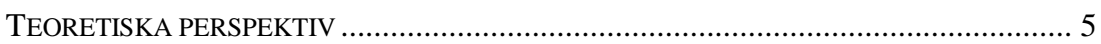

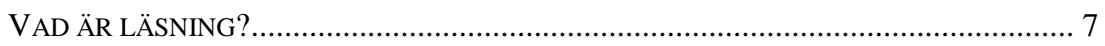

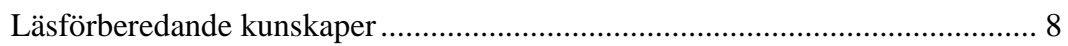

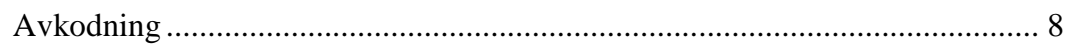

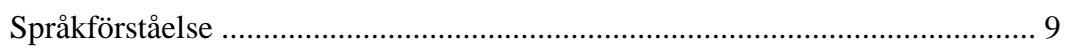

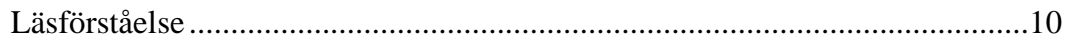

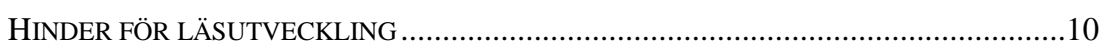

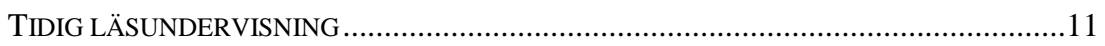

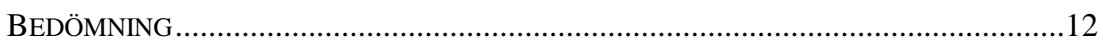

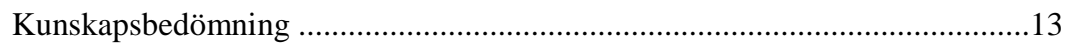

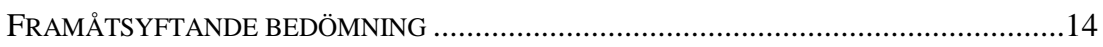

Formativ bedömning och Response to intervention (RTI) i avhandlingen ........15

Formativ bedömning.............................................................................. 15

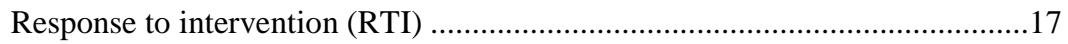

LÄRARES PROFESSIONELLA ANVÄNDNING AV BEDÖMNINGSINFORMATION.............19

BESKRIVNING AV LEGILEXIS VERKTYG OCH TRÄNINGSLÄGRET ....21

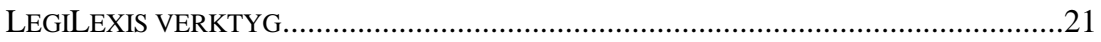

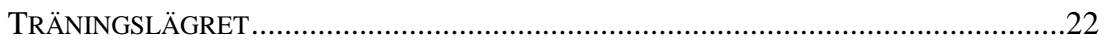

METODOLOGISKA ÖVERVÄGANDEN _....................................................24

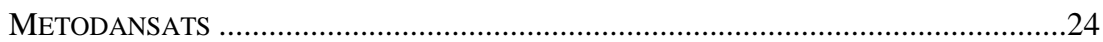

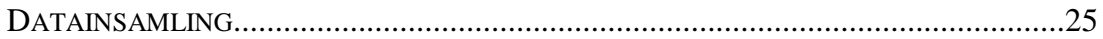

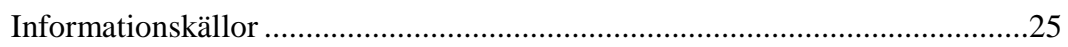

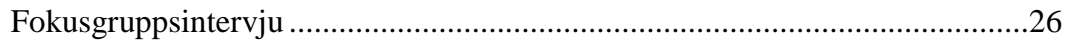

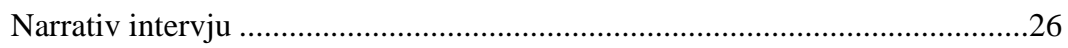

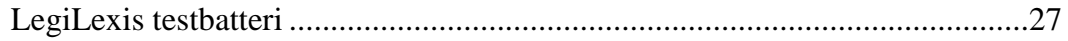

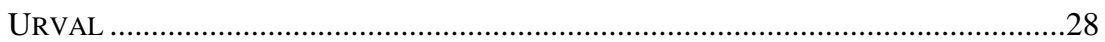

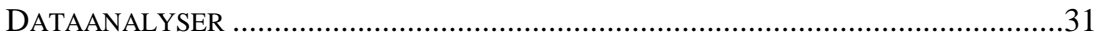

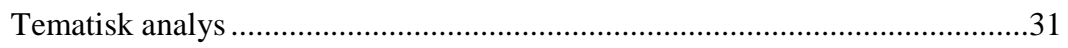

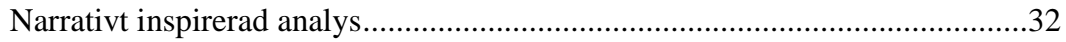

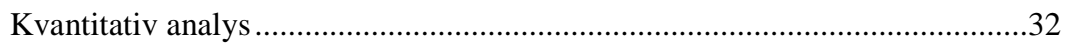

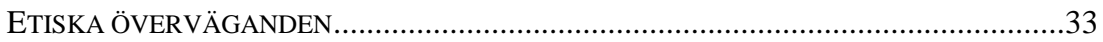

SAMMANFATTNING AV AVHANDLINGENS ARTIKLAR ............................35

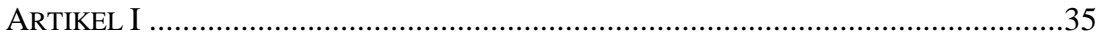

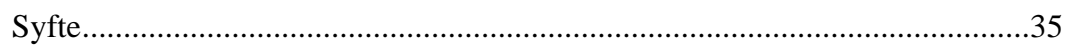

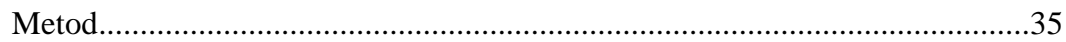

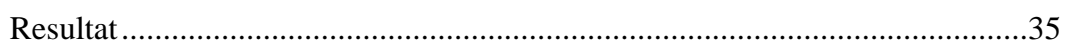




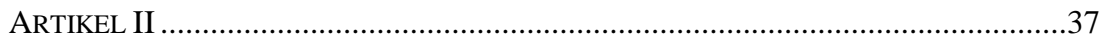

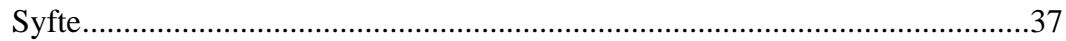

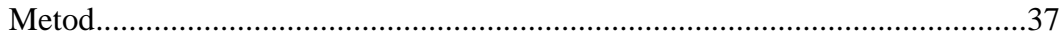

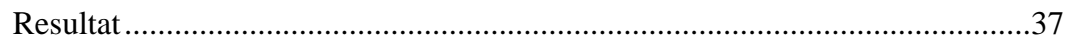

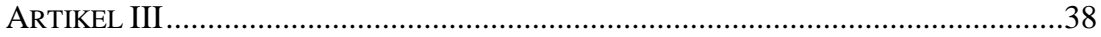

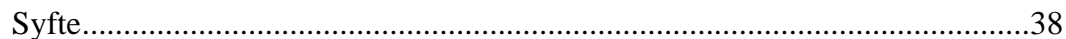

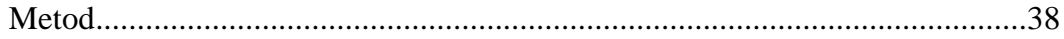

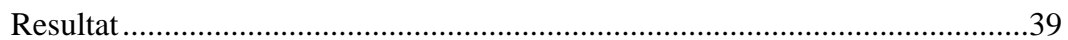

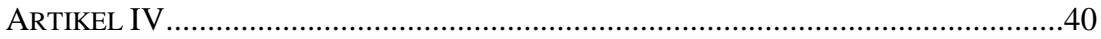

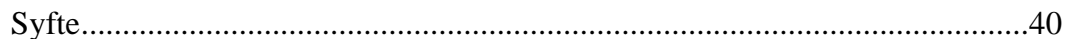

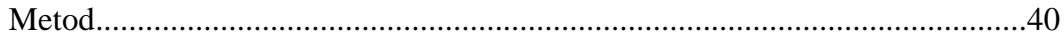

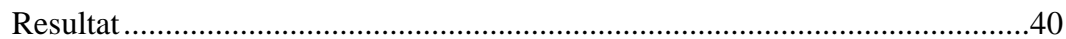

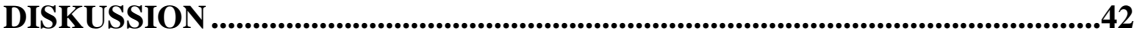

BEDÖMNINGAR FÖR ATT IDENTIFIERA ELEVERS BEHOV OCH ANPASSA

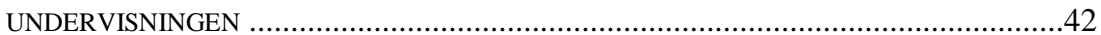

DEN PROFESSIONELLA LÄRAREN OCH STÖDVERKTYGET .........................................46

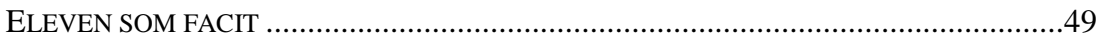

AVHANDLINGENS BEGRÄNSNINGAR OCH STYRKOR ...............................................51

SLUTSATSER OCH PEDAGOGISKA IMPLIKATIONER ...............................53

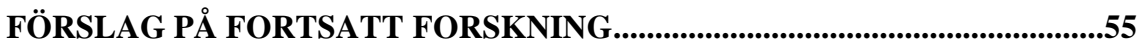

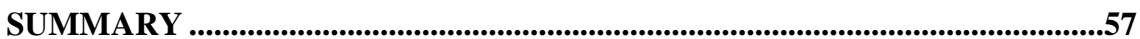

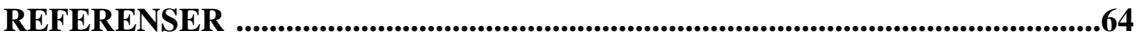




\section{Förteckning över avhandlingens artiklar}

I. Andersson, U. B., Löfgren, H., \& Gustafson, S. (2019). Forwardlooking assessments that support students' learning: A comparative analysis of two approaches. Studies in Educational Evaluation, 60, 109-116.

II. Nordström, T., Andersson, U. B., Fälth, L., \& Gustafson, S. (2019). Teacher inquiry of using assessments and recommendations in teaching early reading. Studies in Educational Evaluation, 63, 916.

III. Andersson, U. B., \& Löfgren, H. (under utgivning). Bedömningar för anpassning i tidig läsundervisning: Lärares erfarenheter av att utveckla elevers avkodningsförmåga. Pedagogisk forskning $i$ Sverige.

VI. Andersson, U. B., Danielsson, H., Nordström, T., Fälth, L., \& Gustafson, S. (inskickad). Effects of a forward-looking assessment tool with provided recommendations for teachers in early reading instruction. 


\section{Inledning}

Att kunna läsa kan beskrivas som att ha tillgång till en nyckel som öppnar dörrar och ger möjligheter att uppleva, tolka, förstå, delta och påverka det samhälle vi lever i och världen runt oss. Att kunna läsa erbjuder också åtkomst till historien och tillgång till fantasivärldar. Läsning stimulerar abstrakt tänkande och är språkutvecklande. Det är ett verktyg för kunskapsinhämtning, rekreation och förströelse. God läsförmåga är också väsentligt för att kunna delta fullt ut i ett demokratiskt samhälle.

För att kunna läsa krävs flera olika förmågor ${ }^{1}$, som elever ska få stöd och hjälp att utveckla och utmanas i genom skolans undervisning. I arbetet med att utveckla elevers läsning är kunskap om läsutveckling och bedömning av läsförmågor nödvändigt. Läsundervisning handlar för läraren om att fortlöpande använda dessa kunskaper som grund och utgångspunkt för de pedagogiska åtgärder som genomförs i klassrummet. Den här avhandlingen handlar om hur framåtsyftande bedömning kan användas och används av lärare för att stödja elevernas läsutveckling i tidig läsundervisning. Bedömning handlar i denna avhandling om att värdera elevers kunskaper, förmågor och behov i relation till tidig läsundervisning. För det krävs information som är väsentlig för att eleverna ska utveckla läsförståelse. I avhandlingen samlar lärarna in bedömningsinformation med hjälp av till exempel testresultat, resultat från kartläggningar och observationer från tidigare eller pågående undervisning. Insamlingsmetoderna som används av lärare i avhandlingens studier är med andra ord både kvantitativa och kvalitativa och inkluderar kognitiva såväl som sociala bedömningsaspekter (jfr McMillan, 2017).

Begreppet framåtsyftande bedömning är hämtat från avhandlingens första artikel där en jämförelse mellan formativ bedömning och Response to intervention (RTI) görs. I studien belyses hur teoretiska kunskaper kan komma till praktisk användning i klassrummet och hur de båda olika förhållningssätten formativ bedömning och RTI kan utveckla lärares professionella bedömarkompetens och bidra till att elevens framtida kunskapsbehov ${ }^{2}$ och välbefinnande identifieras och följs (Andersson m.fl., 2019).

\footnotetext{
${ }^{1}$ I likhet med Skolverket (2011) används begreppet förmåga som ett paraplybegrepp som inkluderar kunskapsformerna fakta, förståelse, färdighet och förtrogenhet. I avhandlingen används begreppet förmåga även för att beskriva elevens pågående läsutveckling, det vill säga "nuvarande kapacitet att göra något specifikt" (Korp, 2011, s 49). Begreppet läsförmåga kan ses som en komplex och handlingsinriktad kunskapsform”, menar Korp, (2011, s 49).

2 Jfr Lgr1 1 (Skolverket, 2011) och Skollagen (2010:800).
} 
I avhandlingen handlar elevernas läsutveckling i tidig läsundervisning främst om generell (typisk) läsutveckling på svenska. Avhandling tar sin lästeoretiska utgångspunkt i The Simple View of Reading (Gough \& Tunmer, 1986) som med hjälp av en förenklad modell beskriver läsning som produkten av avkodning och språkförståelse. Av dessa faktorer intresserar jag mig främst för avkodningsförmågan eftersom den är av störst betydelse tidigt i läsundervisningen (Adams, 1990).

I avhandlingen fokuseras lärares bedömningsanvändning $\mathrm{i}$ läsundervisningen, vilket är ett område där fler studier efterfrågas (Wayman \& Wallace m.fl., 2007). Av vad som framgår i tidigare forskning om läs- och skrivundervisning är kopplingen mellan bedömning och pedagogisk åtgärd en kritisk aspekt i läsundervisningen. Det viktiga är att identifiera elevernas styrkor och svagheter och använda informationen för att skräddarsy undervisningen (Høien \& Lundberg, 2013; Moats, 2009). I det arbetet kan strukturerade, heltäckande program och lärarverktyg vara ett stöd, framför allt för den oerfarne läraren. Den professionella lärarens förmåga att analysera undervisningen och dra slutsatser om elevens kunskapsutveckling kan de däremot inte ersätta menar Moats (2009) i en forskningsöversikt om läs- och skrivundervisning. Det är framför allt studier som undersöker hur lärare analyserar och använder bedömningsinformation för att forma sin undervisning så att den leder till elevens ökade lärande som eftersöks, menar Hirsh och Lindberg (2015) i en forskningsrapport om formativ bedömning. I rapporten där de kartlagt formativ bedömning i svensk grundskola och dess motsvarighet internationellt framkommer också att interventionsstudier som visar på effekter av formativ bedömning är förhållandevis vanliga, medan det finns ett underskott av studier där kvalitativa respektive kvantitativa data används i samverkan (Hirsh \& Lindberg, 2015).

Genom att studera hur lärare använder sig av ett lärarverktyg för den tidiga läsundervisningen, antingen LegiLexi eller Träningslägret, fokuseras $i$ avhandlingen kopplingen mellan bedömning och pedagogisk åtgärd (se vidare $\mathrm{i}$ kapitlet Beskrivning av två läsutvecklingsverktyg). Avsikten med de båda verktygen är att via läraren bidra till högre måluppfyllelse i läsning.

Avhandlingens syfte och forskningsfrågor besvaras med hjälp av de fyra artiklarna (se Tabell 1). Metodvalen har styrts av artiklarnas syfte och frågeställningar.

Avhandlingens undertitel innehåller orden teori och praktik. Med teori åsyftas det teoretiska bidraget i Artikel 1. Det är ett bedömningsteoretiskt perspektiv som belyser hur framåtsyftande bedömning kan användas för att anpassa undervisningen med utgångspunkt i elevernas behov. Med praktik avses lärarens bedömningspraktik, så som den framträder genom avhandlingens artiklar II, III och IV. 


\section{Syfte och forskningsfrågor}

Avhandlingens övergripande syfte är att bidra med kunskap om hur framåtsyftande bedömning kan användas och används av lärare som underlag för pedagogiska åtgärder och anpassningar $i$ tidig läsundervisning. Genom att studera kopplingen mellan bedömning och åtgärder och anpassningar med hjälp av olika perspektiv vill jag bidra med förståelse av hur lärare använder bedömning i sin läsundervisning. Min långsiktiga ambition är att bidra till elevers tidiga läsutveckling och ett delsyfte i avhandlingen är att beskriva och analysera olika möjliga effekter av lärares bedömningsarbete på elevers tidiga läsutveckling.

Avhandlingens kunskapsbidrag kan vara av intresse för, och användas av, såväl läs- och bedömningsforskare som verksamma lärare och skolledare i grundskolan. Förhoppningen är att kunskapsbidraget även kan vara av intresse för blivande lärare och andra som av olika anledningar är engagerade $i$ tidig läsundervisning och bedömningsfrågor kopplade till den. Nedanstående tre forskningsfrågor har drivit avhandlingsarbetet framåt.

a. Hur kan lärares användning av framåtsyftande bedömning i tidig läsutveckling ta sig uttryck i teori och praktik?

b. Vilka professionella överväganden framträder som betydelsefulla i lärares berättelser om att använda framåtsyftande bedömning med stöd av lärarverktyg i tidig läsundervisning?

c. Vilka effekter kan lärarnas användning av bedömningsverktyg ha på elevers tidiga läsutveckling?

Fråga a besvaras i samtliga fyra artiklar. Fråga $\mathrm{b}$ besvaras i Artikel II och III. Fråga c besvaras av Artikel I och Artikel IV.

\section{Avgränsningar}

Bedömningsinformation används av och intresserar fler än läraren i klassrummet. Inom ramen för avhandlingen studeras inte föräldrars intresse av bedömningsinformation, elevers själv- och kamratbedömning, betyg eller resultatjämförelser av skilda slag. Bedömningsinformation som underlag för skolutveckling behandlas inte heller i denna avhandling.

Den här avhandlingen kommer inte att handla om summativ bedömning. Begreppet summativ bedömning förekommer, men då för att kontrastera mot framåtriktade bedömningar som fokuseras här.

Skrivning studeras inte i avhandlingen, även om det finns samband mellan läsning och skrivning och båda förmågorna är viktiga. I avhandlingen studerar jag inte olika skolformer. Det är tidig läsundervisning som är $\mathrm{i}$ fokus och $\mathrm{i}$ avhandlingen genomförs den $\mathrm{i}$ förskoleklass och årskurs 1-3. 


\section{Teori och tidigare forskning}

Följande kapitel belyser teorier och tidigare forskning inom områdena läsning och bedömning. Kapitlet inleds med en beskrivning av avhandlingens teoretiska perspektiv. Sedan följer en beskrivning av teorier och tidigare forskning om läsning, läsutveckling, bedömning och lärares användning av bedömningsinformation.

\section{Teoretiska perspektiv}

Här belyses pragmatismen och avhandlingens teoretiska perspektiv som kan kopplas till läsning, framåtsyftande bedömning och lärares professionalism. Pragmatismen (Dewey, 2009; Feilzer, 2010) bidrar genom sitt holistiska förhållningssätt till teori och praktik med en grund utifrån vilken avhandlingen har utvecklats.

Begreppet pragmatism kan förklaras genom ordet pragma, resultat av handling (Cherryholmes, 2000), och syftar på pragmatismens fokus på de praktiska konsekvenser som kan bli följden då en idé eller teori används. Inom pragmatismen förstås kunskap utifrån de handlingar som utförs och har en tydlig koppling till praktisk nytta och möjligheten för människor att använda kunskapen i sin vardag. Det ligger delvis i linje med avhandlingens syfte där koppling mellan teori och praktisk nytta kan ses när det handlar om hur lärare använder framåtsyftande bedömning $\mathrm{i}$ tidig läsundervisning för att lära elever att läsa. Teori och praktik beskrivs som varsin sida av samma mynt (Dewey, 2009; Hartman, 2012).

I linje med pragmatismen (Dewey, 2009; Feilzer, 2010) har jag ett öppet förhållningssätt till olika teoretiska perspektiv (se även metoddelen). Det betyder att jag intresserar mig för och drar nytta av de olika perspektivens syn på kunskap och hur kunskap kan utvecklas, formas och bedömas. Det finns inslag av såväl det sociokulturella som det kognitiva och beteendeorienterade perspektivet $\mathrm{i}$ den här avhandlingen. De fyller olika funktioner inom områdena läsning och framåtsyftande bedömning.

Det framgår i pragmatismen att även om handlingen är central så behöver reflektion följa $i$ handlingens spår för att utveckla erfarenhet som kan leda till användbar kunskap (Burman, 2014; Dewey, 2009). Kunskap beskrivs som föränderlig. Det framgår att Dewey uppmanar till gemensam kontinuerlig eftertanke och reflektion. Detta ligger i linje med de delar $\mathrm{i}$ avhandlingen som handlar om lärares professionalism där ett reflekterande förhållningssätt ses som en av flera betydande aspekter.

Handling och reflektion ligger i linje med det kognitiva perspektivet och kan kopplas till de delar i avhandlingen som handlar om RTI, det 
vill säga handling (intervention) som följs upp och leder till att nya reflekterade beslut om undervisning kan fattas (jfr Fuchs \& Fuchs, 2006). Genom den starka betoningen på konkreta resultat som visar på förändring över tid kan RTI också kopplas till det beteendeorienterade perspektivet (Fuchs \& Fuchs, 2006; Heward \& Cooper, 1992). Återkoppling till elever kan också ses som en beteendeorienterad aktivitet i klassrummet, under förutsättning att responsen eller konsekvenserna av återkopplingen observeras av läraren (Fuchs \& Fuchs, 2006; Heward \& Cooper , 1992). RTI är central i Artikel I, II och IV.

De teorier och begrepp som handlar om läsning, som till exempel the Simple view of reading (Gough \& Tunmer, 1986), som används i Artikel II, III och IV, tillhör det kognitiva perspektivet. Inom det kognitiva perspektivet riktas intresset mot hur människan tar emot och bearbetar information samt hur vi reagerar på och använder denna information (se t.ex. Piaget, 1964). I artiklarna där utvecklingen av olika läsförmågor hos elever beskrivs används alltså kognitiva begrepp och teorier. Inom detta perspektiv är det vanligt att använda kvantitativa test för att mäta kunskap, vilket görs $\mathrm{i}$ avhandlingens Artikel IV.

När Dewey belyser betydelsen av interaktion avser han interaktion mellan människor, men även med den omgivande miljön (sammanhanget). Genom samspel mellan miljö och människor utvecklas erfarenheter som är av betydelse för kunskapsutvecklingen (Dewey, 2009). Detta ses även inom det sociokulturella perspektivet där miljön, den omgivande kontexten, är av central betydelse för hur kunskap kan utvecklas och förstås (Vygotsky, 1978). Avhandlingens fokus på framåtsyftande bedömning och tidig läsutveckling i svensk grundskola utgör till exempel en specifik kontext som är av betydelse för hur avhandlingen och dess artiklar kan tolkas och förstås.

Skolans läroplan (Lgr11) är ett exempel på en aspekt som har kontextuell påverkan på bedömningspraktiken, eftersom avsikten med den är att styra lärarnas arbete både vad gäller kunskapssyn, ämnesinnehåll och form (förhållningssätt). Interaktion och kontext är också centralt inom det narrativa perspektivet som används för studien i artikel III. Inom detta perspektiv ses berättelser som sociala konstruktioner och meningsskapande handlingar (Mishler 1999; Perez Prieto, 2006). Det betyder att berättelser är dialogiska och tar form i mötet mellan berättare och lyssnare i en specifik kontext (Mishler, 1999). Det sociokulturella perspektivet (Vygotsky, 1978) syns även inom formativ bedömning där interaktion mellan lärare och elever utgör central aspekt för lärande (Wiliam, 2011). Formativ bedömning är central i Artikel I, II och III.

Begreppen och teorierna som nämns i texten ovan ger tillsammans vetenskapliga bidrag till hur elevers tidiga läsutveckling kan bedömas, utvecklas och följas i den bedömningspraktik som utgör avhandlingens 
fokus. De har bidragit till min förståelse av den kontext jag studerar, inte minst genom att synliggöra den mångfald av olika teoretiska perspektiven som inryms $\mathrm{i}$ den tidiga läsundervisningens bedömningspraktik.

I avhandlingens fyra artiklar används, i linje med pragmatismen, olika perspektiv för att studera hur lärare kan använda och använder framåtsyftande bedömning i tidig läsundervisning. Varje artikel lämnar ett kunskapsbidrag och tillsammans inrymmer de olika synsätt på vad kunskap är. Genom att studera framåtsyftande bedömning i tidig läsundervisning ur dessa olika perspektiv kan avhandlingens forskningsfrågor besvaras och lärares arbete inom forskningsfältet belysas på ett sätt som sällan gjorts.

I den följande texten används och beskrivs begrepp och teorier hämtade från de olika teoretiska perspektiven. Texten är strukturerad efter områden som är relevanta för avhandlingens syfte och frågeställningar, under rubrikerna Vad är läsning?, Hinder för läsutveckling, Tidig läsundervisning, Bedömning, Framåtsyftande bedömning samt Lärares professionella användning av bedömningsinformation.

\section{Vad är läsning?}

The Simple View of Reading är en väletablerad och ofta använd teoretisk modell som förklarar läsning som produkten av avkodning och språkförståelse. För att illustrera definitionen används modellen: Läsning = Avkodning x Språkförståelse (Gough \& Tunmer, 1986). Modellen bidrar framför allt med att beskriva variationer av lässvårigheter. För att själv kunna läsa och förstå en text krävs både avkodning och språkförståelse. Svårigheter inom ett område eller inom båda kan leda till tre olika typer av lässvårigheter och kan beskrivas på följande vis: problem med avkodning (t.ex. dyslexi), förståelseproblem, eller problem med både avkodning och förståelse (Aaron, 1997; Catts m.fl., 2003, Elwér, 2014; Gough \& Tunmer, 1986).

Det finns en risk att svårigheter inom något av dessa områden påverkar elevens inställning till läsning och läsundervisning. Till exempel kan problem med avkodning inverka negativt på elevens motivation och lust att läsa. Risken är då att eleven läser färre ord och över tid kanske lär sig förstå färre ord jämfört med de som läser mycket (jfr Matteuseffekten, Stanovich, 1986).

Svårigheter med förståelsekomponenten, det vill säga att tolka och förstå en text, kan bland annat innebära problem med att komma ihåg det just lästa, att sammanfatta och dra slutsatser från texten.

Modellen The Simple View of Reading visar, precis som namnet antyder, en förenklad beskrivning av läsning. Den innebär inte att läsning, eller att lära sig läsa, är enkel utan snarare att variation i läsförmåga kan fångas genom variation inom de båda komponenterna 
(Oakhill m.fl., 2019). The Simple View of Reading är användbar för att förstå typisk läsutveckling, men också variationen av svårigheter som kan hindra elevens läsutveckling (Gustafson m.fl., 2013). I modellen synliggörs betydelsen av de båda komponenterna. Det framgår däremot inte att förhållandet mellan avkodning och språkförståelse förändras över tid och kräver olika grad av uppmärksamhet beroende på var i läsutvecklingen läsaren befinner sig (Elwér, 2014; Gough \& Tunmer, 1986). Tidigare forskning visar att de båda förmågornas betydelse skiftar under den unga elevens läsutveckling. För nybörjarläsaren är avkodningsförmågan den mest väsentliga för att lära sig läsa och följaktligen den som bör ägnas mest uppmärksamhet i ett tidigt skede av läsundervisningen (Adams, 1990; Catts m.fl., 2003; Florit \& Cain, 2011; Rayner m.fl., 2001).

\section{Läsförberedande kunskaper}

I en kunskapsöversikt som handlar om läs- och skrivundervisning för yngre elever belyser Taube och Fredriksson m.fl. (2015) betydelsen av tidiga insatser för att främja den kommande läsinlärningen. Fonologisk medvetenhet och bokstavskunskap utgör grunden för alfabetisk avkodning och benämns ofta som läsförkunskaper (pre-reading skills). Dessa förmågor, som handlar om språkljud, kan redan i förskoleklassen säga något om hur elevens kommande läsutveckling kan komma att se ut (Adams, 1990; Lundberg m.fl., 1988; SBU, 2014; Schuele \& Boudreau, 2008). En elev som är fonologiskt medveten kan prata "om språket", det vill säga skilja på språkets form och innehåll, till exempel skilja på korta och långa ord, rimma, sortera lika ljud och dela upp ord i stavelser. För elever som är i riskzonen för att få lässvårigheter är den fonologiska medvetenheten viktig att uppmärksamma (Lundberg m.fl., 1988; Taube m.fl., 2015).

\section{Avkodning}

Till skillnad från språkförståelse, som börjar utvecklas i spädbarnsåldern, så är det ofta först när eleven möter skolans formella läsundervisning som avkodningsutvecklingen tar fart. Avkodning kallas ibland för den tekniska sidan av läsning. Att avkoda innebär att kunna koppla samman bokstavssymbolen med språkljudet. Det innebär att läsaren får tillgång till ordens mening antingen genom att använda fonologisk avkodning (att koppla samman bokstavsljudet, fonem, med bokstavstecknet, grafem) eller ortografisk avkodning, det vill säga att snabbt läsa hela eller delar av ord (morfem) som en bild (Gustafson m.fl., 2007; Høien, \& Lundberg, 2013).

Elevens avkodningsförmåga förändras över tid. Målet är automatiserad avkodning eftersom den kan ses som en grund och förutsättning för läsförståelse (Høien, \& Lundberg, 2013; Myrberg, 2001). Typisk avkodningsutveckling kan delas in i faserna pseudo- 
läsning (låtsasläsning), logografisk läsning (läsning av sedan tidigare kända ord som ordbilder t.ex. sitt eget och sina kamraters namn, kända loggor), fonologisk avkodning (kopplar samman grafem-fonem och ljudar ihop dessa till ord) och ortografisk-morfemisk (snabb ordbildsläsning av hela, eller delar, av ord). Hur länge läsaren befinner sig i de olika faserna varierar och det är inte ovanligt att läsutvecklingen i de olika faserna sker delvis parallellt med varandra (Høien \& Lundberg, 2013).

En skicklig läsare, som uppnått automatiserad avkodning, avkodar alltså isolerade ord snabbt, korrekt och tyst genom att direkt känna igen orden (Høien \& Lundberg, 2013; Ramus, 2004). Utmärkande för den skickliga avkodaren är förmågan att kunna växla mellan olika avkodningsstrategier utifrån behov. Eleven avkodar då främst ortografiskt, men kan övergå till fonologisk avkodning och ljuda när svåra eller obekanta ord dyker upp i texten (Alatalo, 2011; Høien \& Lundberg, 2013).

Olika avkodningsstrategier ställer krav på olika förmågor vilket är en viktig aspekt att ta hänsyn till vid bedömning av ordavkodningsförmåga hos elever både med och utan läsproblem (Høien \& Lundberg, 2013; Tunmer \& Greaney, 2010). Läsning av pseudo-ord ställer höga krav på fonologisk avkodning, och lämpar sig därför för bedömning av den förmågan. Att läsa "vanliga ord" snabbt på tid (t.ex. under en eller två minuter) ställer krav på visuell snabbhet och lämpar sig väl för bedömning av ortografisk ordavkodningsförmåga.

\section{Språkförståelse}

I The Simple View of Reading ses språkförståelsen som förmågan att använda lexikal information för att tolka talat språk (hörförståelse) (Hoover \& Gough, 1990). Det handlar om att förstå olika texter, handling och budskap eller orsak- verkanförhållanden. Utveckling av språkförståelse startar mycket tidigt, kanske redan i fosterstadiet, och fortsätter att utvecklas hela livet. När eleven börjar skolan är med andra ord språkförståelseutvecklingen redan påbörjad. Språkförståelsen, antingen det gäller hör- eller läsförståelse, byggs upp av en rad förmågor, varav tre framstår som särskilt betydelsefulla; förmågan att kunna aktivera sin bakgrundskunskap, att kunna anpassa sin läsning (eller sitt lyssnande) efter textens struktur och att känna till och använda strategier som ett verktyg för att tolka och förstå olika texters innehåll (Oakhill \& Cain, 2012). De olika förmågorna tar olika lång tid att utveckla och bli förtrogen med. I den tidiga läsundervisningen är det framför allt elevens hörförståelse som aktiveras vid till exempel lärarens högläsning och gemensamma reflektioner runt texter, i samtal och diskussioner med klasskamrater och lärare. I takt med att läsutvecklingen fortskrider får 
språkförståelsen en allt större betydelse för elevens egen läsning (Elwér, 2014; Oakhill m.fl., 2019; Vellutino m.fl., 2007).

\section{Läsförståelse}

Till skillnad från avkodning kan inte läsförståelse automatiseras (Høien \& Lundberg, 2013). Det är möjligt för en god avkodare att läsa upp alla ord i en text, men förstå väldigt lite av innehållet (Elwér, 2014; Oakhill m.fl., 2019).

Läsförståelse kan beskrivas som en flexibel och pågående kognitiv och konstruktiv process, en tvåvägsprocess som integrerar information som hämtas från den lästa texten och tidigare kunskaper genom inferentiell bearbetning (Woolley, 2011). Flera aspekter som är väsentliga för att kommunicera och utveckla språkförståelse är gemensamma med de förmågor som krävs för läsförståelse. De väsentliga skillnaderna, som i sin tur ställer krav på olika strategier, är kommunikationens fysiska form och budskapets sociala funktion (Cain, 2010). Medan det skrivna ordet är permanent och kan läsas om igen, är det talade ordet temporärt och flyktigt, vilket ställer andra krav på minnesfunktioner. Det skrivna ordet ger en visuell bild och det består av bokstäver och skiljetecken enligt en bestämd struktur, medan det talade ordet är auditivt och konstrueras i stunden (Cain, 2010). Forskning visar att det finns ett tydligt samband mellan ordförståelse och läsförståelse. Läsförståelsen är kopplad till både skriven och verbal kommunikation. Båda faktorerna är av avgörande betydelse för läsutvecklingen (Cain, 2010).

\section{Hinder för läsutveckling}

Det finns flera olika hinder för läsutveckling. Hinder utgörs antingen av svårigheter med att avkoda, svårigheter inom språkförståelsefältet eller svårigheter inom båda dessa (Catts m.fl., 2006). Orsaken till läshinder kan vara flera. De kan härledas till olika miljöaspekter där elevens förutsättningar för läsutveckling varit bristfälliga, till exempel dåliga erfarenheter från tidigare skolgång, undermålig undervisning, svåra hemförhållanden, fysisk eller psykisk sjukdom eller en miljö utan kontakt med läs- och skriftspråkliga aktiviteter. Bristande språkkunskaper när svenska inte är modersmål (flerspråkighet) kan också påverka läsutvecklingen.

Funktionsnedsättningar, som till exempel dyslexi och utvecklingsförsening, är andra orsaker som kan bidra till att elevens läsutveckling försvåras (Cain, 2010; Høien \& Lundberg, 2013). Att fastställa de bakomliggande orsakerna till läshinder kan vara ett svårt och komplext arbete, men är väsentligt, inte minst eftersom samma svårigheter kan bero på olika orsaker och kräver olika pedagogiska insatser. Bristfällig undervisning kan i likhet med avkodningssvårigheter resultera i dyslexi. Skillnaden är att medan god 
läsundervisning kan vara tillräckligt stöd för en elev med bristande läserfarenhet, så behöver en person med till exempel dyslexi få en mer specifik och anpassad läsundervisning (Snowling, 2013). Dyslexi kopplas till brister i det fonologiska systemet, vilka för många innebär bestående avkodningssvårigheter (Høien \& Lundberg, 2013; Ramus, 2004; Snowling, 2013).

\section{Tidig läsundervisning}

Målet med undervisningen är förstås att eleverna ska lära sig att läsa. God läsundervisning handlar för läraren om att identifiera elevernas styrkor och svårigheter och att utifrån det systematiskt och strukturerat anpassa undervisningens innehåll och form efter elevernas behov så att de lär sig läsa (Alatalo, 2011; SBU, 2014; Snow \& Juel, 2005). Elevens avkodningsutveckling är en kritisk fas i elevens läsundervisning och det är framför allt $\mathrm{i}$ lågstadiet som den tränas $\mathrm{i}$ strukturerad form. Avkodning är något som lärs in under några år och som då kräver mycket träning för att automatiseras.

Det framgår att systematisk undervisning av bokstäver och ljud bör vara en del av en balanserad undervisning som även inkluderar andra språkliga aktiviteter som till exempel högläsning. Områden att särskilt uppmärksamma $i$ den tidiga läs- och skrivundervisningen är: fonologisk medvetenhet, fonem- grafemkoppling, ordkunskap och stavning, läsflyt, ordförråd, hör- och läsförståelse (Taube m.fl., 2015).

Att lära sig läsa handlar i mångt och mycket om att ägna tid åt att läsa, att träna (Castles m.fl., 2018; Herrlin \& Lundberg, 2014). Träningens goda effekter på specifika förmågor av vikt för elevens läsutveckling belyses i flera studier (Ehri m.fl., 2001; Fälth \& Svensson., 2015; Gustafson m.fl., 2007; Wolff, 2011).

En betydelsefull aspekt för att utveckla god läsförmåga är att läsa med flyt. Exempel på en metod för att träna på detta är att låta eleven läsa samma text flera gånger, så kallad upprepad läsning eller färdighetsträning (Herrlin \& Lundberg, 2014; Taube m.fl. 2015). Färdighetsträningens positiva effekt på elevernas avkodningsförmåga bekräftas i flera interventionsstudier, bland annat i en av Fält m.fl., (2015). Den månadslånga interventionen följde en fastställd och tydlig struktur i form av tio minuters daglig lärarledd individuell lästräning av listor med ord. Av studien framgår att innehållet i interventionerna var anpassas efter elevens kognitiva behov, men också för att bibehålla elevens motivation bland annat genom att visualisera elevens progression. Varierad och flexibel träning, till exempel att kombinera fonologisk avkodningsträning och språkförståelseträning, visade god effekt på elevernas läsutveckling och kunde bidra positivt till både lärares och elevers inställning till själva träningen (Fälth \& Svensson., 2015; Gustafson m.fl., 2011). 
Ett sätt att beskriva balansgången mellan insatsen som undervisningen kräver av eleven och den vinst som eleven upplever av träningen är att likna dem vid "kostnader och utbyte" (Herrlin \& Lundberg, 2014). I en tidigare studie där flera olika påverkansfaktorer på elevers läsmotivation jämfördes framstod både aktivitet och prestation som väsentliga för elevens motivation. Det framgick dock att aktivitetens påverkan på läsmotivationen var av större vikt (Baker \& Wigfield, 1999). Det kan med andra ord vara viktigt att som lärare lägga omsorg på att finna metoder som får eleverna att bli motiverande att läsa. Det kan innebära en utmaning i sig eftersom det är rimligt att tro att elever i en klass motiveras till läsning av olika saker, till exempel av ett tävlingsmoment, av en tilltalande läsmiljö, av bokens utseende eller och dess innehåll, för nytta och nöje. God läsundervisning innebär med andra ord både att eleven bör få hjälp att utveckla "en effektivare ordavkodning och mer automatiserad och mer flytande läsning" (Herrlin \& Lundberg, 2014. s.17) och en vilja att fortsätt lära sig att läsa.

Motsatsen, att inte vilja lära sig läsa, kan uppstå som en följd av upplevda svårigheter och dåligt självförtroende i samband med den tidiga läsundervisningen (Taube, 2013). Genom att uppmärksamma och anpassa undervisningen efter elevernas behov minimeras risken för att elever utvecklar strategier för att slippa läsa (Baker \& Wigfield, 1999; Taube, 2013), halkar efter och riskerar att få bestående lässvårigheter (Gustafson m.fl., 2014; Snow, 1998; Stanovich, 1986).

För elever där tidigare pedagogiska åtgärder inte leder till förväntad läsutveckling kan kompensatoriska hjälpmedel, till exempel assisterande teknik, vara ett alternativ (Fälth \& Svensson, 2015; Jacobson, m.fl., 2009). Med hjälp av dessa kan till exempel elever med dyslexi få stöd i läsningen samtidigt som elevens övriga kunskapsinhämtning inte begränsas på samma vis av de dyslektiska svårigheterna.

Den systematiska och strukturerade läsundervisningens innehåll och genomförande som nämndes tidigare inbegriper alltså en rad didaktiska val vad gäller metoder och material som kan stödja, utmana och locka elever som har lätt för att lära sig läsa, likaväl som de elever som får kämpa mer.

\section{Bedömning}

I följande kapitel belyses forskning om bedömning. Inledningsvis riktas fokus på forskning om kunskapsbedömning. Därefter följer Framåtsyftande bedömning, under denna uppmärksammar jag två närliggande begrepp: Databaserat beslutsfattande (data based decision making) och Bedömning för lärande. Därefter motiverar jag valen att använda formativ bedömning och RTI och under de följande två rubrikerna beskrivs forskning om formativ bedömning respektive RTI. 
Avslutningsvis uppmärksammas forskning om lärares professionella användning av bedömningar.

\section{Kunskapsbedömning}

Synen på kunskap så som den uttrycks i skolans styrdokument har förändrats över tid och har varit avgörande för vad läraren bedömer (mål, normer, kriterier, domäner) och vilka verktyg som används (Carlgren, m.fl., 2009). I dagens läroplan används begreppen fakta, förståelse, färdighet och förtrogenhet för att beskriva olika aspekter av kunskap som eleven ska utveckla och läraren bedöma (Skolverket, 2019). Under de senaste åren har intresset för bedömningsresultat för olika ändamål ökat, liksom kraven på lärares bedömningsarbete (Hirsh, 2017; Korp, 2011). För läraren har det inneburit att kvalitativa bedömningsmetoder och sociala bedömningsaspekter har fătt en allt större betydelse (Korp, 2011; McMillan, 2017). Samtidigt fyller även standardiserade testresultat alltjämt sin funktion, både för arbetet med att anpassa delar av undervisningen och för att tillgodose andra intressenters (t.ex. rektor, föräldrar, politiker, Skolverket) behov av bedömningsresultat (Fuchs \& Fuchs, 2017; Hirsh, 2017; Korp, 2011).

Summativ och formativ bedömning är två vanligt förekommande begrepp i forskning om bedömning och även i klassrumspraktiken. Summativ bedömning beskrivs ofta som bedömning av lärande, medan formativ bedömning beskrivs som bedömning för lärande (Black \& Wiliam, 1998; Taras, 2009). Summativ bedömning används för att summera elevers kunskaper (Scriven, 1967). Exempel på tillfällen då summativ bedömning praktiseras i lågstadiet är de omdömen i olika ämnen som svenska skolelever ska få som en del av en individuell utvecklingsplan (IUP). Ett annat tillfälle när summativ bedömning används är i form av resultaten på nationella prov i årskurs 3. Av tidigare forskning om bedömning framgår att summativ bedömning ofta kopplas samman med betyg, sortering och identitetsskapande (Korp, 2011). Formativ bedömning är till skillnad från den summativa bedömningen inriktad på den pågående processen och utvecklingen framåt. Mål och kriterier är centrala $i$ den formativa bedömningspraktiken och används som drivkraft för att utveckla undervisningen och elevens kunskaper (Sadler, 1989; Wiliam, 2011). I ovanstående resonemang är det syftet som avgör om en bedömning är att betrakta som summativ eller formativ (Scriven, 1967). Taras (2009) har ett annat sätt att se på begreppens förhållande till varandra. Hon argumenterar för att varje formativ bedömning har en summativ start och att de båda begreppen i praktiken hör ihop. När Black och Wiliam (2018) diskuterar begreppen formativ och summativ bedömning konstaterar de att både summativ och formativ bedömning kan behövas för klassrumsbedömning. Det beror på vad läraren ska bedöma eftersom begreppen fyller olika funktion. Hirsh och Lindberg (2015) 
beskriver en framväxande bedömningsförståelse som inkluderar både summativ och formativ bedömning. Min egen förståelse avspeglas i valet att använda begreppet framåtsyftande bedömning. Detta begrepp fokuserar på syftet med bedömningarna. I likhet med Taras (2009) menar jag att en formativ bedömning bör utgå från en slags summering av vad läraren redan vet om elevens förmågor och behov. Detta stämmer också överens med hur bedömningar används inom RTI.

\section{Framåtsyftande bedömning}

Under denna rubrik belyses inledningsvis begreppen framåtsyftande bedömning, databaserat beslutsfattande och bedömning för lärande. Under rubriken Formativ bedömning och RTI i avhandlingen motiverar jag valet att använda dessa förhållningssätt och sedan beskrivs de under varsin rubrik.

I avhandlingen används begreppet framåtsyftande bedömning (jfr Andersson m.fl., 2019). Begreppet är hämtat från studien i Artikel I där vi genom att jämföra två olika framåtsyftande förhållningssätt, formativ bedömning (Wiliam, 2011) och RTI (Grigorenko, 2009), identifierade flera nyckelbegrepp som de har gemensamt och andra som skilde dem åt. Resultaten visar att formativ bedömning och Response to intervention kan komplettera varandra och att kunskap om olika framåtsyftande förhållningssätt och teorier kan underlätta lärares professionella utveckling. Väsentligt för framåtsyftande bedömningar i avhandlingen är att dessa är kopplade till elevens kunskapsutveckling med avsikt att användas av läraren för att antingen göra anpassningar av undervisningen, eller för att ge återkoppling till eleven (Fuchs \& Fuchs, 2006; Wiliam, 2011).

Det finns, jämte formativ bedömning och RTI, flera olika förhållningssätt med framåtsyftande ändamål. Ett näraliggande förhållningssätt är databaserat beslutsfattande vilket kan definieras som ett målmedvetet användande av tolkade data (information) för att följa, utveckla och utvärdera skolans verksamhet på olika nivåer. Det innebär att systematiskt analysera befintliga datakällor (t.ex. skolans organisation, läroplaner eller elevresultat), att använda analysresultat för att genomföra förändringar inom olika områden (t.ex. anpassa undervisningen) och utvärdera det som gjorts (Schildkamp \& Kuiper, 2010).

Bedömning för lärande, är ett annat närliggande förhållningssätt som har sina rötter i formativ bedömning och enligt Leahy och Wiliam (2012) började det användas i bedömningsforskningen i slutet av 1900talet. Black m.fl. (2004) beskriver att skillnaden mellan begreppen kan kopplas till dess syfte och funktion. De beskriver att Bedömning för lärande betonar bedömningarnas syfte medan det $\mathrm{i}$ formativ bedömning riktas fokus mot bedömningens funktion och det beslut som fattas för att anpassa undervisningen efter elevens behov. Det kan 
tolkas som att en bedömning är att betrakta som formativ om den används och fyller en funktion för elevens utveckling framåt (Black m.fl., 2004; Lundahl, 2011). Det finns emellertid olika åsikter och tolkningar vad gäller dessa näraliggande förhållningssätt och att se dem som synonyma förekommer också (Bennett, 2011; Skolverket, 2011).

\section{Formativ bedömning och Response to intervention (RTI) $i$ avhandlingen}

En av anledningarna till valet att använda RTI och formativ bedömning i avhandlingen är de båda förhållningssättens gemensamma fokus på elevens utveckling i relation till den undervisning som ges. En annan anledning är de skillnader, möjligheter och begränsningar som framträder då förhållningssätten beskrivs och jämförs. Av särskilt intresse för avhandlingsarbetet är hur lärare använder bedömningar för att anpassa undervisningen i syfte att utveckla elevers kunskaper (jfr Andersson m.fl., 2019; Nordström m.fl., 2019). Aspekter som också var väsentliga för avhandlingsarbetet var RTI:s fokus på tidig läsundervisning och ett förhållningssätt som fokuserar på verksamhetens förmåga att fånga upp elevers behov (Fuchs \& Fuchs, 2006; Gersten, m.fl., 2020). På denna punkt skiljer sig formativ bedömning och RTI åt. Till skillnad från RTI riktas fokus i formativ bedömning mot interaktionen mellan lärare och elever i klassrummet. Ytterligare en skillnad är utbredningen i svensk skolpraktik. Formativ bedömning är numera ett välkänt begrepp, bland annat genom till exempel stödmaterial för lärare (se Skolverket, 2011) och populärvetenskaplig litteratur. RTI förkommer mera sparsamt i svensk skolkontext (se Response to intervention).

\section{Formativ bedömning}

I forskningslitteratur såväl som i den svenska skolpraktiken har intresset för formativ bedömning ökat under 2000- talet (Hirsh \& Lindberg, 2015). Formativ bedömning beskrivs som ett svar på behovet att förändra kunskapsbedömningarnas användning (funktion) från att summera kunskaper till att fungera som ett pedagogiskt verktyg (Black \& Wiliam, 1998; 2009; Korp, 2011). Formativ bedömning beskrivs också som en framgångsfaktor för att utveckla klassrumsundervisningen och elevens lärande att lära (Black \& Wiliam, 1998; Hattie, 2008; Wiliam, 2011). Det finns även tidigare studier som belyser svårigheter med att implementera och använda formativ bedömning i praktiken (jfr Black, 2015; Jonsson m.fl., 2015; Perrenoud, 1991).

Formativ bedömning kännetecknas, till skillnad från RTI, av att läraren själv ansvarar för att besluta om vilken bedömningsmetod som ska användas (t.ex. observation, lyssna, dialog, test), vad som ska 
bedömas (t.ex. ordavkodning, läsmotivation) och vem som ska bedöma (lärare, elev eller kamrat). Även när och hur bedömningarna genomförs är den enskilda lärarens beslut, liksom hur bedömningarna tolkas och används, antingen för att anpassa undervisningen eller som feedback till elever på individnivå. Formativ bedömning är möjlig att använda i alla skolämnen och på olika vis. Det är läraren som avgör om och hur bedömningsarbetet ska följas upp och det ses som positivt om eleven kan involveras (Heritage, 2013; McMillan, 2017; Wiliam, 2011). I formativ bedömning förespråkas lärar- elev dialog och tydligt uttryckta kunskapsmål och bedömningskriterier för att möjliggöra elevens delaktighet och ansvarstagande i det egna lärandet. Formativ bedömning innebär enligt Wiliam (2011) att fatta beslut om fortsatt undervisning.

Ett första steg i bedömningsprocessen är att tänka igenom vilket underlag, vilken information, som behöver samlas in. Därefter handlar det om att använda bedömningsinformationen för att avgöra vad som är nästa steg i undervisningen (Wiliam, 2011). Följande fem nyckelstrategier är utmärkande för formativ bedömning i skolan: 1) Förtydliga och skapa förståelse för förväntade lärandemål och kriterier för framsteg, 2) Utveckla klassrumspraktiken som synliggör att lärande har skett och att bevis för elevernas prestationer kan samlas in, 3) Ge feedback som leder elevernas utveckling framåt, 4) Aktivera eleverna som resurser för varandras lärande och 5) Aktivera eleverna så att de blir ägare av sitt eget lärande (Wiliam, 2011). Inom ramen för den formativa bedömningen inryms med andra ord både lärarens bedömningsarbete med fokus på att utveckla undervisningen och elevernas egen drivkraft, lära att lära, genom lärarens feedback, självoch kamratbedömning. I avhandlingen fokuseras de bedömningar som görs av lärare i syfte att anpassa sin undervisning.

En betydande uppgift för läraren i det formativa klassrummet är att skapa en undervisning där dialog och interaktion mellan lärare och elev och mellan elever utgör väsentliga delar. Kommunikationen kan användas för att bedöma elevernas behov och främja deras läsutveckling (Applebee m.fl., 2003; Howe \& Abedin, 2013; Wiliam, 2011). Den formativa bedömningspraktiken ställer krav på såväl lärarens som elevens kompetens vad gäller formativ bedömning. Det handlar om att använda mål i undervisningen, att utveckla elevens metakognition och att kunna interagera och kommunicera i olika gruppkonstellationer. För detta krävs att läraren ägnar tid åt att stödja och träna eleverna i det arbetet (Baines, m.fl., 2009; Mercer m.fl., 2004; Perrenoud, 1991). Brist på fördjupad kunskap och förståelse om den formativa bedömningspraktiken ökar risken för att så kallade pseudo-formativa praktiker utvecklas, det vill säga att förståelsen av formativ bedömning blir instrumentell och innebär ett mer vanemässigt användande av olika metoder för metodernas skull (Birenbaum m.fl., 2011; Lauvås \& Jönsson, 2019). Detta kan sägas vara motsatsen till en 
mer önskvärd formativ bedömningspraktik där det centrala är elevarbetens kvalitet, att involvera och stödja eleven i det egna lärandet och att ge återkoppling. För att stödja det formativa bedömningsarbetet förespråkar Lauvås och Jönsson (2019) att formativ och summativ bedömning hålls åtskilda i så stor utsträckning som möjligt. De menar att en kombination av summativ och formativ bedömning riskerar att leda till fler oönskade effekter, inte minst för eleven, än de som kan uppstå då de används var för sig, till exempel vad gäller elevens kunskapsutveckling, självkänsla och motivation (Lauvås \& Jönsson, 2019).

I en intervjustudie där elevernas erfarenheter av lärarnas bedömning fokuseras beskrivs ett kontraproduktivt bedömningsparadigm som i likhet med den pseudo-formativa praktiken ovan riskerar att leda till oönskade effekter (Hirsh, 2020). I studien beskriver eleverna som är i 16-18 årsåldern att de upplever stark press, osäkerhet och ett minskat intresse (motivation) för skolarbetet kopplat till den bedömningspraktik som de själva är en del av. Resultaten i denna studie kan inte tydligt kopplas till summativ eller formativ bedömning, utan snarare till mängden bedömningar och de instruktioner som följer i dess spår (Hirsh, 2020).

\section{Response to intervention (RTI)}

Response to intervention utmärks av en målstyrd och tydlig struktur med systematisk och återkommande testning av elevers förmågor (Fuchs \& Fuchs, 2006). Inom denna tradition är målet att förhindra tidiga läsproblem genom att tillhandahålla alltmer anpassade och mer intensiva läsinstruktioner (Vaughn \& Fuchs, 2003). Det görs med hjälp av standardiserade test för att identifiera elevernas svårigheter på detaljnivå inom ett specifikt skolämne (till exempel läsning).

Utvecklingen av RTI går tillbaka till 1960-talet då det utvecklades av forskare i USA. Det beskrivs både som ett förhållningssätt för att identifiera läsare med låg läsförmåga, en specialpedagogisk metod, men även som en metod för att identifiera elevers rätt till specialundervisning (Fuchs, m.fl., 2012). RTI har i USA sedan år 2004 använts i syfte att förebygga tidiga skolmisslyckanden, efter en förändrad lagstiftning (Fuchs \& Fuchs, 2006). RTI har ett tydligt fokus på verksamhetens förmåga att identifiera och anpassa undervisningen med vetenskapligt grundade metoder. Till skillnad från formativ bedömning, där bedömningsmetoderna kan variera, används alltid standardiserade test. Resultaten från dessa ligger sedan till grund för utformandet av vetenskapligt beprövade interventioner där eleven får träna på de förmågor där eleven uppvisar svårigheter. Interventionerna baseras på testresultaten och kan beskrivas som tre olika nivåer (tiers) för att möta elevens specifika behov av undervisningsinnehåll och graden av individualisering (se Figur 1). Det handlar med andra ord 
om undervisning $\mathrm{i}$ generell klassrumsundervisning, undervisning $\mathrm{i}$ mindre grupp (riktad undervisning), eller en-till-en undervisning (specialiserad undervisning) (Fuchs \& Fuchs, 2006). Tier 1 som genomförs som en del av den generella klassundervisningen är inte föremål för RTI-forskningen i samma utsträckning som övriga tiers (Lam \& McMaster, 2014). Det är dock i den generella undervisningen i klassrummet som de inledande bedömningarna av elevernas läsutveckling och behov av stöd görs. Om lärarens generella klassrumsundervisning inte håller god kvalitet kommer det framför allt att påverka de elever som behöver mer stöd (Alatalo, 2011; Høien, \& Lundberg, 2013).

\begin{tabular}{|l|}
\hline Tier 3, specialiserad under- \\
visning (t.ex. av special- \\
lärare eller logoped). \\
Återkommande testning \\
görs för att noggrant följa \\
individuell utveckling efter \\
mer intensiv undervisning \\
enskilt eller i små grupper. \\
Tier 2, riktad och mer \\
intensiv undervisning i \\
mindre grupper. Ater- \\
kommande testning görs \\
för att noggrant följa \\
elevers utveckling och \\
anpassa undervisningen. \\
Tier 1, generell, ordinarie, \\
klassundervisning, baserad \\
på bedömning av test- \\
resultat. Elever kan flyttas \\
upp eller ner i modellen \\
utifrån sina testresultat.
\end{tabular}

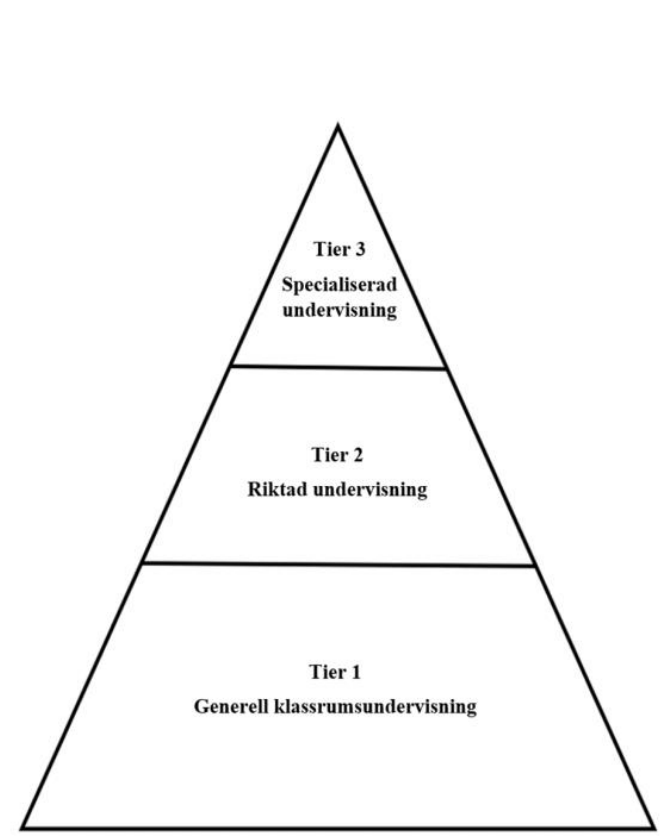

Figur 1. Tredelad RTI-modell. Egen bearbetning efter Fuchs och Fuchs (2006).

Det bör tilläggas att RTI kan utformas på olika vis utifrån olika skolors behov och möjligheter. Nordström (2018) presenterar till exempel en fjärde nivå (tier) som inkluderar assisterande teknik. Fuchs och Fuchs (2009) ger exempel på en RTI-design innehållande två tiers och Berkeley m.fl. (2009) ger exempel på att så många som sju tiers praktiseras. RTI-strukturen innebär att en genomförd intervention följs av testning för att kontrollera effekten av den och för att få vägledning inför fortsatt undervisning (Fuchs \& Fuchs, 2006). 


\section{Lärares professionella användning av bedömningsinformation}

I de tidigare kapitlen beskrivs förmågor och kompetenser inom läsning och framåtsyftande bedömning som krävs för att elever ska utvecklas till goda läsare. För läraren handlar det om att möta olika elevers behov av stöd och utmaningar.

För lärare som undervisar i svensk grundskola och vill använda någon form av stöd $\mathrm{i}$ sin läsundervisning finns den möjligheten, till exempel i form av olika bedömningsverktyg, kartläggningsmaterial och screening-test. I avhandlingens Artikel II och IV användes LegiLexis verktyg och i Artikel III användes Träningslägret (de beskrivs mer utförligt i följande kapitel. Bedömningsverktyg är dock inte som självspelande pianon och de förutsätter ofta att läraren kan tolka den information som verktyget ger och kan omsätta denna i praktisk handling (Gersten m.fl., 2020; Herrlin \& Lundberg, 2014). Om och hur läraren kan använda verktyget kan kopplas till dess utformning. En studie av Zeuch m.fl. (2017) visar till exempel att bedömningsverktyg som ger en alltför detaljerad och omfattande bedömningsinformation kan vara en utmaning för läraren. Risken är att informationen, i stället för att användas för att utveckla undervisningen, främst används som ett mått på elevens prestation.

Flera tidigare studier belyser lärares svårigheter med att använda bedömningsinformation för att anpassa undervisningen (Alatalo, 2011; Means m.fl., 2011; Schildkamp \& Kuiper, 2010). Det som framstår som den verkliga utmaningen för läraren är att förstå vad eleven behöver öva på och hur undervisningen då ska utformas (van den Bosch, m.fl., 2017). Det krävs både teoretisk kompetens och praktisk förmåga för att bedriva undervisning så att den leder till att eleverna trots olika förutsättningar och förkunskaper lär sig läsa (Alatalo, 2011; Høien \& Lundberg, 2013).

Hur läraren tar sig an arbetet med bedömningsverktyg kan kopplas till lärares professionalism sett utifrån perspektivet där en gemensam vetenskaplig grund och teoretisk förankring utgör en grund. Denna grund kan fungera som stöd för egen eller kollegial problemlösning och stöd för beslutsfattande, till exempel i samband med användning av bedömningsverktyg. Kopplingen mellan vetenskapliga teorier, bruket av ett gemensamt yrkesspråk och förståelse för den egna professionens innehåll och yrkesutövande är även dessa kännetecknande för professionalism (Colnerud \& Granström, 2015). Den professionella läraren kan också kännas igen genom förmågan att fatta välgrundade beslut utifrån elev- och undervisningsbehov samt genom reflektioner och överväganden (Biesta m.fl., 2015). Exempel på motsatsen till den professionella lärarens förmåga att fatta välgrundade och reflekterade beslut skulle då kunna vara ett mer instrumentellt, vanemässigt sätt att använda ett formativt bedömningsverktyg eller en 
metod, som en följd av otillräcklig kunskap och kompetens (Birenbaum m.fl., 2011; Gardner, 2012). Tidigare studier visar att det kan ta många år att utveckla den yrkeskompetens som utmärker en professionell lärare (Colnerud \& Granström, 2015; van den Hurk m.fl., 2016) och att anpassa undervisning räknas som något av det mest avancerade inom läraryrket (van de Grift, 2007). Mot bakgrund av detta belyser van den Hurk m.fl., (2016) betydelsen av att läraren får stöd i att tolka och använda bedömningsinformation. Blanc m.fl. (2010) för ett liknande resonemang och menar att lärares kompetens formas i den egna kontexten och att ordentligt stöd från skolledning kan leda till mer effektiv användning av bedömningsinformation.

Den omgivande kontextens betydelse för hur metoder kan implementeras och användas i bedömningspraktiken poängteras också av Hirsh (2020). I avhandlingskontexten handlar det om bedömningars användbarhet och hållbarhet för att utveckla undervisningen och elevers läsförmåga, på kort och lång sikt (Andersson, 2021; Levin, 2013).

Ytterligare en aspekt som kan kopplas till professionalism och som är av intresse för avhandlingen är den professionellas rätt och skyldighet att själv besluta om de arbetsmetoder och verktyg som läraren ska använda (Colnerud \& Granström, 2015). Det är ett perspektiv som ställer krav på lärares ansvar samtidigt som det ger läraren stora friheter. Den svenska lärarens grad av professionalism kopplad till just detta är inte given eftersom läraren har att förhålla sig till exempel obligatoriskt bedömningsverktyg i årskurs 1 (Skolverket, u.å.). Denna spänning mellan att begränsa och främja lärarens professionella handlingsutrymme syns inom utbildningspolitiken i flera länder (Biesta m.fl., 2015; Hirsh \& Lindberg, 2015). Förespråkare som uttrycker fördelar med att begränsa lärarens handlingsutrymme kan ofta kopplas till evidensbaserade och datadrivna undervisningsoch bedömningsmetoder, medan andra belyser läraryrkets komplexitet och betydelsen av den professionella lärarens handlingsutrymme för god undervisning (Biesta m.fl., 2015). 


\section{Beskrivning av LegiLexis verktyg och Träningslägret}

Här presenteras två olika verktyg för att stödja lärares arbete med läsutveckling. Det är lärares arbete inom ramen för dessa som studeras i avhandlingens artiklar II-IV. De båda verktygen är utvecklade för att stödja lärarens framåtsyftande bedömningsarbete. Verktygen och stöden de ger till lärarna är också tänkta att bidra till lärarnas professionella utveckling inom området läsundervisning. Inledningsvis beskrivs LegiLexis verktyg, som lärarna i Artikel II och IV använder sig av. Därefter följer en presentation av Träningslägret som lärarna i Artikel III använder.

\section{LegiLexis verktyg}

LegiLexi är en opolitisk och icke vinstdrivande stiftelse med visionen att alla barn ska lära sig att läsa ordentligt under lågstadiet i svenska skolan (LegiLexi, u.å.). För att nå målet vänder sig stiftelsen till lärare och erbjuder dessa ett digitalt verktyg. Syftet med detta är att fungera kompetensutvecklande och stödjande för främst lågstadielärare. Det består bland annat av test, övningar, böcker, artiklar och appar. Verktyget ska vara användarvänligt och fungera som stöd för ett formativt och adaptivt arbetssätt och läraren väljer själv hur och i vilken omfattning materialet ska användas $i$ den egna läsundervisningen. LegiLexis verktyg och de tjänster som erbjuds är baserade på forskning och beprövad erfarenhet. Verktyget har sin teoretiska grund i The Simple View of Reading (Gough \& Tunmer, 1986), RTI och formativ bedömning (se Teori och tidigare forskning). Lästesten är utvecklade i nära samarbete med forskare från Linköpings universitet och Linnéuniversitetet $\mathrm{i}$ Växjö och bygger på beprövade testmetoder och relevant forskning (LegiLexi, u.å). Verktyget är gratis att använda för lärare i Sverige (LegiLexi, u.å.).

LegiLexis verktyg utvecklades ur ett projekt som startades 2014 av Bertil Hult, grundare av EF Education First, och Martin Ingvar, professor på Karolinska Institutet, som båda två har ett stort intresse för att alla barn ska lära sig läsa. Initiativtagare till projektet och tillika finansiär var Bertil Hult. För att kvalitetssäkra verktyget har LegiLexi sedan starten haft en referensgrupp bestående av svenska forskare som bland annat har haft i uppdrag att granska materialet (LegiLexi, u.å.). I januari 2021 hade 21000 lärare spridda över landets 290 kommuner registrerat sig som användare av LegiLexis verktyg.

LegiLexis test kartlägger elevers läsfärdigheter. Testen mäter elevers läsförkunskaper (fonologisk medvetenhet och bokstavskunskap), avkodningsförmåga, språkförståelse och 
läsförståelse samt elevernas inställning till att lära sig läsa. Testbatteriet genomförs tre gånger per läsår, höst, vinter och vår. Av sammanlagt nio test görs sju individuellt på en Ipad eller med papper och penna, medan två test (pseudo-ordavkodning och ordavkodning) måste göras en-till-en.

Elevernas testresultat rättas digitalt och läraren får tillgång till resultaten på individ- och klassnivå. Resultaten från samtliga deltest ligger till grund för ett rekommenderat fokusområde, det vill säga ett förslag på ett kortsiktigt undervisningsmål fram till nästa testtillfälle (t.ex. avkodning). Läraren får också en individuell rekommendation för varje elev. Den individuella rekommendationen baseras på samtliga deltest och ger en mer detaljerad bild av vilka områden eleven borde fokusera på för att komma vidare i sin läsutveckling. Varje elevs individuella prestationer finns redovisade per deltest $i$ ett stapeldiagram. Där redovisas de senaste tre genomförda testomgångarnas resultat. Avsikten är att visa elevens progression inom respektive område.

Läraren kan med ledning av testresultat, rekommendationer och övriga stödfunktioner välja hur undervisningen ska genomföras i klassrummet (LegiLexi, u.å.).

\section{Träningslägret}

Träningslägret var ett småskaligt läsutvecklingsprojekt organiserat för två grundskolor, en F-6 skola och en F-3 skola. Det utvecklades 2016 av områdets speciallärare, inspirerat av dennas tidigare erfarenheter av läsundervisning och läsprojekt, i samråd med rektorsområdets lärare och skolledning. Till skillnad från LegiLexis verktyg kan Träningslägret beskrivas som en lokal lässatsning där deltagandet är obligatoriskt. Bakgrunden till läsprojektet var ett identifierat behov av att utveckla elevernas avkodningsförmåga. Sportmetaforen Träningsläger med tillhörande träningspass valde lärarna främst för att motivera till avkodningsträning, men även för att visa att läsning består av flera delar som man behöver träna på för att bli en god läsare. Sedan starten hade Träningslägret utvidgats spontant inom rektorsområdet och engagerade förutom elever, lärare och föräldrar med anknytning till de två låg- och mellanstadieskolorna, även förskoleklass och fritidshem. När denna studie gjordes, hösten 2018, genomfördes Träningslägret för andra året i rad och det fanns en långsiktig plan på att fortsätta arbetet.

Träningslägret kan beskrivas som en generell insats med fastställd struktur för bedömningsarbetet och standardiserat anpassade undervisningsmoment för varierad avkodningsträning. Träningslägret ramades in av för- och eftertest (H4) som avsåg att mäta elevernas avkodningsutveckling. Träningslägret hade 2018, vid tiden för den här 
studien, genomförts två gånger och resultaten visade, enligt de ansvariga på skolorna, på positiv avkodningsutveckling på individnivå.

Träningslägret genomfördes under en 4-veckorsperiod i anslutning till terminsstart. Förskoleklass och årskurserna 1-3 följde en gemensamt fastställd struktur med dagliga standardiserade anpassningar baserade på bedömningsresultaten. De dagliga momenten hette uppvärmning, match, teknikträning och snack med coachen.

Lärarens roll var att följa den fastställda strukturen med sitt innehåll och stödja det pågående arbetet enligt schemat. Efter träningstidens slut rättade läraren själv elevernas arbeten.

Det första momentet var uppvärmning, eleverna högläste listor med ord för att träna på avkodning. Varje par skulle ha en nivåanpassad lista. Listläsningen pågick i en minut per elev. Om listan lästes färdigt så skulle de börja om på nytt.

Det andra momentet var match. Eleverna läste parläsning högt för varandra ur varsin likadan bok. Böckerna valde paret i samråd med klassläraren. De första två veckorna läste de i en skönlitterär bok, de två andra veckorna i en faktabok. De läste varannan sida under 10 minuter, den som inte läste skulle enligt instruktionen följa med i texten.

Det tredje momentet var 10 minuters teknikträning. Teknikträningen syftade till att utveckla handstilen, befästa bokstävernas utseende och träna grundläggande skrivregler på olika nivåer (använda rader, skriva stor bokstav, mellanrum och punkt). Det gick till så att eleverna valde ut ett ord, en mening eller ett stycke i den nyligen lästa boken och skrev av detta i en egen skrivbok.

Det fjärde och sista momentet hette Snack med coachen. Det var en självbedömningsuppgift som låg i slutet av ett träningspass. Arbetet i Träningslägret dokumenterades på ett veckoschema. Vid behov (för lätt, för svårt, färdig) bytte läraren ut läslistor och böcker. Inför själva träningspasset uppmanades elevparen att gå till sina förutbestämda platser, i eller i anslutning till klassrummet. När alla hade satt sig på sina platser startade läraren tidtagningen och paren började arbeta med de olika momenten enligt schemat. 


\section{Metodologiska överväganden}

I följande kapitel beskriver och motiverar jag metodval och metoder som ligger till grund för Artikel I, II, III och IV och som tillsammans besvarar avhandlingens frågeställningar.

\section{Metodansats}

Avhandlingens övergripande syfte är att bidra med kunskap om hur framåtsyftande bedömning kan användas och används av lärare som underlag för pedagogiska åtgärder i tidig läsundervisning. För att studera det beaktar jag olika aspekter av hur lärare kan använda och använder bedömning. Metodansatsen i avhandlingen speglar de fyra artiklarnas skilda perspektiv, vart och ett valt för att besvara den enskilda studiens syfte och frågeställningar. Denna ansats kan liknas vid det praktiska och resultatinriktade förhållningssätt som beskrivs inom pragmatismen (Dewey, 2009; Johnson \& Onwuegbuzie, 2004). Inom pragmatismen beskrivs ett öppet förhållningssätt till kunskap (Dewey, 2009), det vill säga att det finns en öppenhet för att använda både kvantitativa och kvalitativa metoder för att studera ett fenomen, liksom en naturlig koppling mellan teori och praktik. Poängen är att forskningsmetoderna blandas på ett sätt som ger de bästa möjligheterna för att svara på viktiga forskningsfrågor (Johnson \& Onwuegbuzie, 2004). I avhandlingen betyder det att de olika artiklarnas syfte och frågeställningar varit vägledande för val av datainsamlingsmetod och analysförfarande. Ambitionen med dessa val har aldrig varit att ge en fullständig bild av hur lärare använder bedömningsinformation för att anpassa undervisningen, utan att belysa detta från olika perspektiv och med hjälp av olika metoder. I likhet med Creswell och Creswell (2017) menar jag att avhandlingens kvantitativa och kvalitativa metoder kan bidra på olika sätt och att en kombinerad användning kan ge en utökad förståelse för det område som studeras.

I avhandlingen används kvantitativ metod i Artikel IV. Kvantitativ metod kan användas då det handlar om att söka samband, beskriva, mäta eller förklara resultat i form av siffror. Med hjälp av statistik och standardiserade test är det möjligt att samla in och överblicka en större mängd information, jämföra, upptäcka skillnader i resultat mellan olika testtillfällen, individer och grupper och att studera effekter av undervisningen över tid (jfr Artikel IV; Gustafson m.fl., 2019). Information från det urval som görs kan användas för att dra slutsatser om en större population. Med hjälp av statistiska metoder är det möjligt att (under vissa förutsättningar) studera sannolikheten för att det som gäller i urvalsgruppen även gäller i populationen, det vill säga att generalisera resultaten statistiskt. Inom kvalitativ forskning finns det andra begrepp som handlar om möjligheten att generalisera 
resultat, såsom till exempel igenkänning eller överföring (Larsson, 2009). I Artikel IV använde vi ett kvasiexperiment och resultaten analyserades kvantitativt. En fördel med denna design och metod var att den möjliggör uttalanden om orsakssamband mellan olika variabler.

I jämförelse med kvalitativa metoder är kvantitativa resultat ofta begränsade på så sätt att de inte innehåller kontextuell information om eleven, den som testar och testsituationen. Det är däremot fullt möjligt att jämföra olika kontexter med varandra i en kvantitativ undersökning, till exempel att jämföra två olika klassrum med varandra kvantitativt. Kvalitativ metod som jag använt i Artikel II och III kan däremot inkludera, eller till och med handla om, de olika kontexter där lärande sker.

I avhandlingens Artikel II och III använder jag mig av kvalitativ intervju, dels fokusgruppsintervju (Breen, 2006) dels narrativ intervju (Perez Prieto, 2006). I Artikel II använde vi fokusgruppsintervju för att locka våra deltagande lärare till samtal och diskussion om hur de använde LegiLexis bedömningsverktyg i sin egen undervisning. Avsikten med att använda fokusgruppsintervju var att lärarna inom gruppen skulle inspireras av varandras beskrivna upplevelser av att använda verktyget och utifrån dessa delade erfarenheter vidga och fördjupa samtalet.

I Artikel III använde vi oss av individuella och narrativt inspirerade semistrukturerade intervjuer för att få kunskap om hur lärare anpassar sin undervisning i relation till gjorda bedömningar. Studiens medverkande lärare uppmanades att berätta om och ge exempel från sitt arbete med Träningslägret. Intervjuformen valdes med tanke på studiens forskningsfrågor där vi sökte lärares tolkade förståelse av sina specifika erfarenheter. Poängen med att använda berättelser är just att få åtkomst till vad lärarna berättar om sina upplevelser inom en specifik kontext (Perez Prieto, 2006).

Avhandlingens teoretiska perspektiv (se Teori och tidigare forskning), olika metoder och skilda sätt att analysera insamlade data, har ställt krav på kunskaper och kompetens inom flera olika områden (se Avhandlingens begränsningar och styrkor för fortsatt diskussion).

\section{Datainsamling}

\section{Informationskällor}

För att finna källor och information för avhandlingsarbetet med artiklarna I, II, III och IV samt kappan, har jag använt mig av olika strategier. En har varit att använda söktjänsterna LIBRIS, Diva, SwePub, ERIC och Google Scholar. Följande sökord och kombinationer av dessa på svenska och engelska låg till grund för sökningarna: bedömning, formativ bedömning, RTI, dataanvändning i undervisning, framåtsyftande bedömning, läsning, läsförståelse, 
avkodning, framåtsyftande bedömning, bedömning för lärande, läsundervisning, dyslexi, lässvårigheter, och lärares professionalism.

En annan strategi har varit att använda LiUs bibliotekstjänster för att hitta och få tillgång till Peer-review artiklar, doktorsavhandlingar, bokkapitel. Det har också många gånger varit så att en intressant källa bidragit till att jag funnit fler genom att söka i referenslistorna.

\section{Fokusgruppsintervju}

Fokusgruppsintervju användes för att samla in data i Artikel II. Intervjuerna genomfördes av mig under vårterminen 2016. Inför intervjuerna fick lärarna information om studien, frågan om deltagande och samtycke samt studiens användning i linje med Vetenskapsrådets (2017) publikation God forskningssed.

För att underlätta lärarnas deltagande genomfördes fokusgruppsintervjuerna $i$ en större svensk stad med goda kommunikationsmöjligheter.

En kort stund innan respektive fokusgruppsintervju startade träffades forskaren och lärare i intervjulokalen för ett kort informellt samtal. Syftet med detta var att värma upp, låta lärarna lära känna varandra lite, för att på så vis skapa en trygg och trivsam intervjuatmosfär och stimulera lärarnas vilja att dela med sig av sina erfarenheter (Breen, 2006; Krueger, 2000).

Som stöd under intervjun användes en öppen semistrukturerad intervjuguide. Intervjuguiden innehöll ett flertal rubriker som stöd för samtalet, där den första handlade om lärarnas kännedom om att använda framåtsyftande bedömning. Den andra rubriken handlade om lärarnas användning av tester och läsprofiler. Den tredje var inriktad på fokusområden för undervisningen genom rekommendationer på individ- och klassnivå och den fjärde handlade om möjligheter och begränsningar med att använda undervisningsrekommendationer.

Vid första intervjutillfället spelades samtalet in med både ljud och bild för att underlätta transkriberingsarbetet. Det visade sig att bilden inte underlättade arbetet varför detta uteslöts vid det andra fokusgruppstillfället.

\section{Narrativ intervju}

Narrativ intervju användes för datainsamling till studien i Artikel III. Vi valde narrativ metod för att studera hur lärare använder bedömning inom den specifika kontext som utgörs av Träningslägret. I likhet med Goodson och Sikes (2001) menar jag att det primära syftet med en narrativt inriktad ansats är att undersöka hur människor, enskilda eller i grupper, förstår och skapar identitet och mening i sina liv. Med hjälp av narrativ ansats är det möjligt att genom berättelser närma sig studiens lärare, deras erfarenheter och meningsskapande inom ramen för läsprojektet. I likhet med Goodson och Sikes (2001), betraktar jag 
berättelser som en viktig källa till kunskap om lärares professionella arbete. I likhet med Mishler (1999) och Perez Prieto (2006) kan berättelser ses som sociala konstruktioner och meningsskapande handlingar. Det betyder att berättelser är dialogiska och tar form i mötet mellan berättare och lyssnare i en specifik kontext (Mishler, 1999). Berättelserna kan bidra med kunskap om lärares erfarenheter och meningsskapande som kan tolkas i relation till sin kontext. För att underlätta de 12 lärarnas deltagande genomfördes de individuella intervjuerna på lärarnas respektive skola under tider som de själva valde.

Inför intervjuerna fick lärarna information om studien och dess användning. De tillfrågades också om deltagande och om samtycke i linje med Vetenskapsrådets forskningsetiska principer (2017).

Informationen inför intervjutillfället innehöll bland annat en planerad tidsåtgång på två timmar per intervju. Genom att avsätta en förhållandevis lång tid avsåg vi att stödja lärarnas möjligheter att berätta i lugn och ro om sina erfarenheter och sitt arbete med Träningslägret (jfr Goodson \& Sikes, 2001). Inför intervjuerna hade en intervjuguide utarbetats; denna fanns med som stöd vid intervjuerna, men det var framför allt lärarnas egna berättelser och de vägar dessa tog som var $\mathrm{i}$ fokus under intervjuerna. Vanliga frågor och uppmaningar som användes var "Berätta om..." och "Hur gör du då, berätta?", avsikten var att likt Goodson och Sikes (2001) uppmuntra lärarna att berätta om sina praktiska erfarenheter. Intervjuerna spelades in på diktafon och har transkriberats.

\section{LegiLexis testbatteri}

Att genomföra LegiLexis test digitalt krävde vid tiden för studiens datainsamling (läsåret 2016/2017) individuell tillgång till Ipads eller Chromebooks och ett fungerande nätverk. Inför testningen krävdes en del administration som till exempel att skapa ett LegiLexi-konto och att som lärare registrera sig som användare och skapa en digital klass. Läraren hanterade sin egen och sina elevers individuella inloggningsuppgifter. Instruktioner för detta fanns i en skriftlig manual och support erbjöds av projektledningen.

I LegiLexis testbatteri fanns nio olika deltest som avsåg att kartlägga olika läsfärdigheter. De fyra första deltesten (del 1) handlade om elevernas läsförkunskaper (fonologisk medvetenhet och bokstavskunskap) och språkförståelse (ordförråd och hörförståelse). Dessa test krävde ingen egen läsning av eleven och information om genomförandet gavs muntligt via hörlurar. Efter en introduktion av klassläraren och instruktioner om genomförandet arbetade de flesta eleverna på egen hand med testen. Beräknad tidsåtgång för den första delen var cirka 15-35 minuter. 
Del 2 innehöll tre deltest som avsåg att mäta elevens läsförståelse (enkel och avancerad läsförståelse samt läsförståelse av faktatext). Dessa test var tidsbegränsade. Eleverna arbetade på egen hand digitalt med hörlurar. Beräknad tidsåtgång var 5-20 minuter. Testet för enklare läsförståelse bestod av 12 korta texter, totalt 12 frågor. Avancerad läsförståelse bestod av sex längre texter med sammanlagt 18 frågor. Läsförståelse av faktatext bestod av fyra texter och totalt 12 frågor.

Del 3 innehöll två deltest som avsåg att mäta elevernas avkodningsförmåga (snabbläsning av riktiga ord och snabbläsning av nonsensord) på 1 minut. Dessa tester genomfördes en-till-en (lärareelev). Första gången testerna genomförs startar alla från deltest 1 . Lärarens roll var att informera om hur och varför eleverna skulle göra lästesten, finnas till hands för att stödja och hjälpa eleverna under tiden. Deltest 1-7 var självinstruerande och deltest 8 och 9 (avkodningstest) testades individuellt.

Eleverna uppmanades att lyssna noggrant på frågorna och försöka hitta rätt bland alternativen. Vid behov kunde frågan upprepas genom ett knapptryck. Eleverna behövde hjälp med att komma i gång, till exempel med att få på sig och ställa in hörlurar och med att ta fram rätt elev i den digitala enheten. Det gick att starta i olika delar av testbatteriet, pausa och fortsätta vid senare tillfälle. Eftersom eleverna hade hörlurar var det möjligt för en hel klass att genomföra de första sju testen samtidigt och begränsningen var tillgången på digitala enheter och nätverkets funktion. Avkodningstesten krävde en-till-en organisation. Instruktionen där handlade om att läsa så många ord som möjligt på en minut (Fälth m.fl., 2017).

\section{Urval}

Artikel I beskrev och jämförde vi två framåtsyftande förhållningssätt för bedömning, formativ bedömning och RTI. Som stöd för urvalet av artiklar beslutade vi oss för att stöd av en definition av formativ bedömning av Wiliam (2011) respektive Grigorenko (2009) för en beskrivning av RTI. Dessa båda är väl etablerade forskare inom respektive fält och vi tyckte att deras definitioner underlättade vårt arbete. Wiliam uttrycker följande för att definiera formativ bedömning (2011).

"En bedömning fungerar formativt i den utsträckning som bevis om elevernas prestationer uppmärksammas, tolkas och används av lärare, elever eller deras kamrater för att fatta beslut om nästa steg i undervisningen som sannolikt är bättre eller bättre grundade än beslut de skulle ha fattat $\mathrm{i}$ 
avsaknad av bevisen" (Egen översättning efter Wiliam, 2011, s.43.).

Grigorenko (2009) beskriver RTI som att:

’[...] försöka hitta det bästa sättet att utbilda barn genom att ta hänsyn till svarsmönster och justera pedagogiska insatser beroende på dessa svar". (Egen översättning efter Grigorenko, 2009, p 114).

Vi sökte efter relevant litteratur med hjälp av databaser (se Informationskällor) och i redan funna artiklar (jfr snöbollsurval t.ex. Creswell \& Creswell, 2017). Exempel på sökord som vi använde var: bedömning, formativ bedömning, RTI, dataanvändning i undervisning, framåtsyftande bedömning, och bedömning för lärande.

Vi avgränsade vår sökning till vetenskapligt granskade artiklar, översikter och bokkapitel av etablerade forskare på området. Som vägledning i arbetet med att finna artiklar använde vi oss framför allt av artiklarnas användbarhet med utgångspunkt i studiens syfte och frågeställningar. Artikeln ska inte betraktas som en systematisk litteraturstudie utan snarare som en teoretisk artikel där begrepp och två förhållningssätt inom området framåtsyftande bedömningar relateras till varandra.

I Artikel II avsåg vi att studera lågstadielärares användning av framåtsyftande bedömning, inklusive undervisningsrekommendationer för att anpassa undervisningen efter elevernas individuella behov. Vi sökte efter lärare som använde LegiLexis verktyg och som var ansvariga för den tidiga läsundervisningen $\mathrm{i}$ årskurs $1-3 \mathrm{i}$ sina respektive klasser. Via LegiLexis projektledare fick vi kontakt med 25 lärare som alla valt att använda LegiLexis verktyg. Av dessa 25 lärare var det tio som ställde sig positiva till att medverka i studien. De lärare som valde att inte delta angav bland annat hög arbetsbelastning som orsak till att de avböjde. Vid tiden för intervjuerna hade antalet deltagare sjunkit ytterligare, bland annat på grund av sjukdom. Eftersom vi hade svårt att finna deltagare för studien beslutade vi oss för att genomföra intervjuerna med de lärare som vi hade och låta kvaliteten på de insamlade uppgifterna vara vägledande för dess användbarhet, snarare än antalet deltagare. I studien deltog åtta kvinnliga lärare som arbetade i årskurs 1-3, vilka kom från olika skolor i flera kommuner. Lärarna i studien började använda LegiLexis verktyg samtidigt, precis då LegiLexi gjordes offentligt och det var möjligt att börja använda verktyget. Lärarna hade olika lång erfarenhet av läraryrket. Storleken på klasserna skilde sig åt, men bestod ofta av 20-28 elever. Några av lärarna använde LegiLexis verktyg tillsammans med en kollega medan andra var ensamma användare på sin skola. De hade vid tiden för intervjuerna använt verktyget i 6-8 månader. I 
samband med att de började använda verktyget hade de deltagit i en obligatorisk läskurs, fått två undervisningsrekommendationer och tillgång till information om läsning och läsundervisning.

I Artikel III avsåg vi att bidra med kunskap om lärares arbete med att använda bedömningsinformation som underlag för anpassningar i läsundervisning med fokus på avkodning. För denna studie tillfrågades de lärare som hade klassansvar och som tillsammans med sina elever var engagerade i det lokalt organiserade Träningslägret. Studiens fokus på tidig läsinlärning och framåtsyftande bedömning låg till grund för valet av lärare kopplade till förskoleklass, årskurs 1-3 och fritidshem. Samtliga lärare som arbetade med åldersgruppen tillfrågades och samtliga valde att delta. I studien medverkade 12 lärare varav två förskollärare, åtta lärare i årskurs 1-3 varav tre med specialpedagogisk kompetens och två lärare från fritidshemmet. Bakgrunden till urvalet var det intresse som väcktes då vi genom skolutvecklingsgruppen (rektor, utvecklingsledare och lärare) på de två skolorna fick kännedom om skolornas satsning på avkodningsundervisning. Vårt beslut att genomföra studien grundades till stor del på skolutvecklingsgruppens beskrivning av förbättrad avkodningsförmåga för så gott som samtliga deltagande elever. Skolornas mätmetoder var dock inte genomförda på ett vetenskapligt och helt systematiskt sätt och redovisas därför inte $\mathrm{i}$ artikeln. Ytterligare en aspekt som bidrog till valet att studera lärarnas bedömningsarbete inom Träningslägret var att det genomfördes för tredje gången, vilket vi menar bidrog till en viss kontinuitet och erfarenhet av genomförandet. Även skolutvecklingsgruppens engagemang för läsutveckling baserad på bedömningar och deras intresse av att delta $\mathrm{i}$ studien bidrog till vårt urval för denna studie. I Artikel III presenteras tre berättelser. De har valts ut eftersom de illustrerar en spännvidd avseende olika typer av bedömnings- och anpassningshandlingar i såväl förskoleklass som i de tidiga skolåren (se Artikel III för mer detaljer).

I Artikel IV avsåg vi att bidra med kunskap om effekterna av att använda ett bedömningsverktyg och rekommendationer för tidig läsundervisning samt kunskap om variation bland elever som initialt var dåliga avkodare och deras läsutveckling i årskurs 1 . För att få tillgång till data för studien i Artikel IV vände vi oss till LegiLexis projektledare. Vi fick genom dem tillgång till anonymiserade testresultat från elever vars lärare hade valt att använda LegiLexis verktyg som en del av sin undervisning.

$\mathrm{Vi}$ skapade två grupper baserat på elevernas testresultat vid testtillfälle 1 och 2: Non-responders (elevgrupp som genom testresultat inte svarade på undervisningen) och Responders (elevgrupp som genom testresultat svarade på undervisningen). Vi samlade också in data om elever som fungerade som en jämförelsegrupp.

Deltagarna var 2749 elever i årskurs 1. Responders-gruppen bestod av 674 elever, från 92 olika skolor, uppdelade i 170 klasser. Non- 
responders-gruppen bestod av 2075 elever, från 102 grundskolor, uppdelade i 200 olika klasser. Jämförelsegruppen bestod av 71 elever i årskurs 1 från 10 klasser och 8 olika grundskolor. Alla elever följde den svenska grundskolans kursplan för årskurs 1-3 (Skolverket, 2011). Skolorna var spridda över hela Sverige och varierade med avseende på socioekonomiska förhållanden, storlek och geografiskt läge, det vill säga det var en blandning av stads-och landsbygdsskolor.

För att erhålla en avkodningsrekommendation var eleven tvungen att prestera lågt både på ordavkodningstestet ( $<40$ korrekta ord) och pseudo-ordavkodningstestet ( $<16$ korrekta icke-ord), annars gavs en annan rekommendation. Av de elever vars data passerade vår kvalitetskontroll fick 55,9\% en avkodningsrekommendation vid T1, och 47,3\% vid T2. Non-responders-gruppen fick en avkodningsrekommendation efter både hösten (T1) och vintertestningen (T2). Responders-gruppen fick en avkodningsrekommendation efter hösttestningen och en annan rekommendation (som inte var avkodning) efter vintertestningen. Jämförelsegruppen testades med LegiLexis testbatteri men fick inga rekommendationer baserat på sina resultat förrän datainsamlingen var avslutad.

\section{Dataanalyser}

\section{Tematisk analys}

I Artikel II har vi använt oss av tematisk analys. De transkriberade intervjuerna analyserades av alla fyra författarna med utgångspunkt från riktlinjer för innehållsanalys och sambedömning mellan kollegor (Creswell \& Miller, 2000; Creswell \& Poth, 2017). För att undvika bias (t.ex. påverkan av forskarens eventuella fördomar) jämfördes försteförfattarens och övriga författares kodning under hela analysprocessen, till dess att vi kunde identifiera innebördsrika och representativa teman. I den analytiska processen sökte vi efter mönster för hur lärarna beskrev sin praktik och hur de använde verktyget i sin undervisning.

Vid den tematiska analysen användes sexstegsförfarandet (Braun \& Clarke, 2006), vilket betyder att den analytiska processen var rekursiv och vi sökte efter återkommande teman. Jag genomförde intervjuerna och utgick ifrån en intervjuguide men det fanns gott om möjligheter för lärarna att ta upp och utveckla ämnen som forskargruppen inte hade tänkt på före intervjuerna. Hur diskussionerna utvecklades var olika i de två grupperna, emellertid hittades teman i båda fokusgrupperna. Vissa beskrivningar kodades som tillhörande flera olika teman. 


\section{Narrativt inspirerad analys}

I Artikel III har vi använt oss av narrativt inspirerad analys. Den narrativa analysen gör det möjligt att studera hur lärare, i sina berättelser om gjorda bedömningar och anpassningar, motiverar de handlingar de anser bidrar till förbättrad avkodningsförmåga hos eleverna. Temporaliteten, det vill säga tidsordningen, fyller en viktig funktion i analysen och den gör det möjligt att identifiera narrativa enheter i berättelsen (Labov \& Waletzky, 1967/1997). Detta görs då olika bedömnings- och anpassningshandlingar knyts till varandra och organiseras på ett sätt som ger dem mening i relation till varandra. Det möjliggör för berättaren att dra sina slutsatser om varför just dessa handlingar var relevanta.

Analysen genomfördes $\mathrm{i}$ tre steg. Först identifierades lärares bedömningshandlingar i transkripten. Dessa kännetecknades av att läraren på något sätt samlade in information om eleverna som hade betydelse för den anpassning som sedan gjordes. Gemensamt för samtliga bedömningshandlingar som studerades var att de var framåtsyftande och låg till grund för en nära förestående anpassning som är motiverades av läraren.

Nästa steg i analysen innebar att de narrativa enheterna i lärarnas berättelser identifierades. Det gjordes genom att studera hur bedömningshandlingarna ledde till specifika anpassningshandlingar.

Det tredje analyssteget riktades mot de motiveringar som framträdde i lärarnas berättelser och som kopplades till specifika bedömnings- och anpassningshandlingar.

Varje narrativ enhet som studerades avslutades med en evaluering och resolution (Labov \& Waletzky, 1967/1997) där läraren tillskrev berättelsen en viss betydelse med en grad av allmängiltighet. Det handlar om hur läraren motiverar att specifika bedömnings- och anpassningshandlingar faktiskt leder till att elever blir bättre på att avkoda.

\section{Kvantitativ analys}

För studiens design i Artikel IV lämpade sig variansanalys (ANOVA). En fördel med denna analysmetod är att många jämförelser, mellan grupper och mellan olika mättillfällen, kan göras i en och samma statistiska analys. Därigenom minskas risken för att göra typ 1-fel, det vill säga att hävda att det fanns en signifikant skillnad när skillnaden $\mathrm{i}$ själva verket berodde på slumpen.

Studien baserades på en $3 \times 3$ design med de oberoende variablerna Grupp (Responders, Non-responders, och jämförelsegrupp) och Testtillfälle (T1, T2 och T3) som oberoende variabler och åtta olika läsrelaterade förmågor som beroende variabler.

$\mathrm{Vi}$ använde statistikprogrammet $\mathrm{R}$ ( $\mathrm{R}$ Core Team, 2019) och RStudio (RStudio Team, 2020) för alla analyser. 
För att besvara den första forskningsfrågan användes beskrivande statistik. Den andra och den tredje forskningsfrågan besvarades med separata 3 x 3 variansanalyser för varje test med Grupp som en oberoende mellangruppsvariabel och testtillfälle som en oberoende inomgruppsvariabel.

\section{Etiska överväganden}

Inför studierna i Artikel II och IV skickades en etikprövning in till Etikprövningsnämnden i Linköping (EPN) för forskning inom LegiLexi (Ref. 2015/208-31). I en kommentar uttrycktes att etikprövning inte behövdes då aktiviteterna sågs som en del av ordinarie skolverksamhet och eftersom de i första hand riktades mot lärare och inte direkt mot elever (det var ingen traditionell interventionsundersökning utan ett verktyg för lärare).

Inför studierna i Artikel II och III informerade vi lärarna om den aktuella studien skriftligt och muntligt i linje med God forskningssed (Vetenskapsrådet, 2017). Informationen bestod av en beskrivning av studiens syfte, användning av resultat och hantering av insamlade data (konfidentialitet). Vi frågade om lärarnas medverkan, beskrev vad vi förväntade oss av deras deltagande (t.ex. tidsåtgång, genomförande) och frågade om deras samtycke till att delta. Vi informerade också om lärarnas möjlighet att avbryta sin medverkan i studien och om anonymisering av information, till exempel namn på personer och platser. Denna information gavs också till lärare, elever och vårdnadshavare inför datainsamling för kontrollgruppen som ingick $\mathrm{i}$ Artikel IV.

För studien i Artikel IV fick vi genom stiftelsen LegiLexi tillgång till avidentifierade testresultat i form av siffror från elever i årskurs 1 . Kodnyckeln administrerades av LegiLexi och forskargruppen kände inte till elevernas eller lärarnas namn. Under detta läsår fick inte kontrollgruppens lärare tillgång till någon resultatinformation eller rekommendationer. I forskargruppen diskuterade vi den balansgång som våra behov av en kontrollgrupp för forskning, kontra lärares och elevers ökade arbetsinsats. Detta resulterade i att vi erbjöd kontrollgruppens lärare att få tillgång till sina elevers resultat och stöd med att tolka dessa efter avslutad studie.

Min relation till Stiftelsen LegiLexi består i att jag till viss del medverkat i att utveckla bedömningsverktyget tillsammans med övriga medlemmar i forskargruppen och projektledarna, samlat in data för kontrollgruppen och använt resultat från stiftelsens databas. Det finns ingen ekonomisk koppling mellan mig och stiftelsen och jag har inte varit anställd av LegiLexi. Min relation till Träningslägerskolorna i Artikel III, har bestått i att jag har samlat in data för denna studie. Det finns inga ekonomiska kopplingar mellan mig och dessa skolor. I samband med de empiriska studierna var min avsikt att hålla isär 
forskning och undervisning och undvika att hamna i en lärarroll eller rådgivande roll när det gällde skol-, elev- eller läsrelaterade frågor. 


\section{Sammanfattning av avhandlingens artiklar}

Här presenteras en sammanfattning av Artikel I-IV, var och en för sig.

\section{Artikel I}

Andersson, U. B., Löfgren, H., \& Gustafson, S. (2019). Forwardlooking assessments that support students' learning: A comparative analysis of two approaches. Studies in Educational Evaluation, 60, 109-116.

\section{Syfte}

Syftet med studien var att bidra med insikter och kunskap som kan medverka till att forskare och lärare kan fatta mer informerade beslut om framåtsyftande bedömningar för att stödja elevers lärande.

\section{Metod}

För att finna relevant litteratur, främst vetenskapligt granskade artiklar, om formativ bedömning och RTI sökte vi i databaser (se rubrik och informationskällor) och framför allt i redan funna artiklar (jfr snöbollsurval). Urvalet grundades i artiklarnas relevans kopplade till studiens syfte och frågeställningar (se urval).

Parallellt med att vi läste artiklar och diskuterade innehåll i relation till studiens syfte och frågeställningar identifierades sju nyckelstrategier för formativ bedömning respektive RTI. För analysen använde vi ett Venn-diagram för att belysa både de unika nyckelaspekterna för formativ bedömning respektive RTI och de aspekter som vi fann att de hade gemensamt.

\section{Resultat}

För formativ bedömning var de sju nyckelstrategierna; Klassrumskontext, Elevernas engagemang, Feedback till elever, Framåtsyftande bedömning, Mål och kriterier, Bedömningskompetens och Kvalitativt fokus.

Nyckelstrategier för RTI var; Systematisk organisation, Databaserat beslutsfattande, Evidensbaserad undervisning, Framåtsyftande bedömning, Mål och kriterier, Bedömningskompetens och Standardiserade tester. Av dessa fann vi tre aspekter som identifierades som gemensamma för både formativ bedömning och RTI; Framåtsyftande bedömning, Mål och kriterier, och Bedömningskompetens (se Figur 2). 
Formativ bedömning Response to intervention

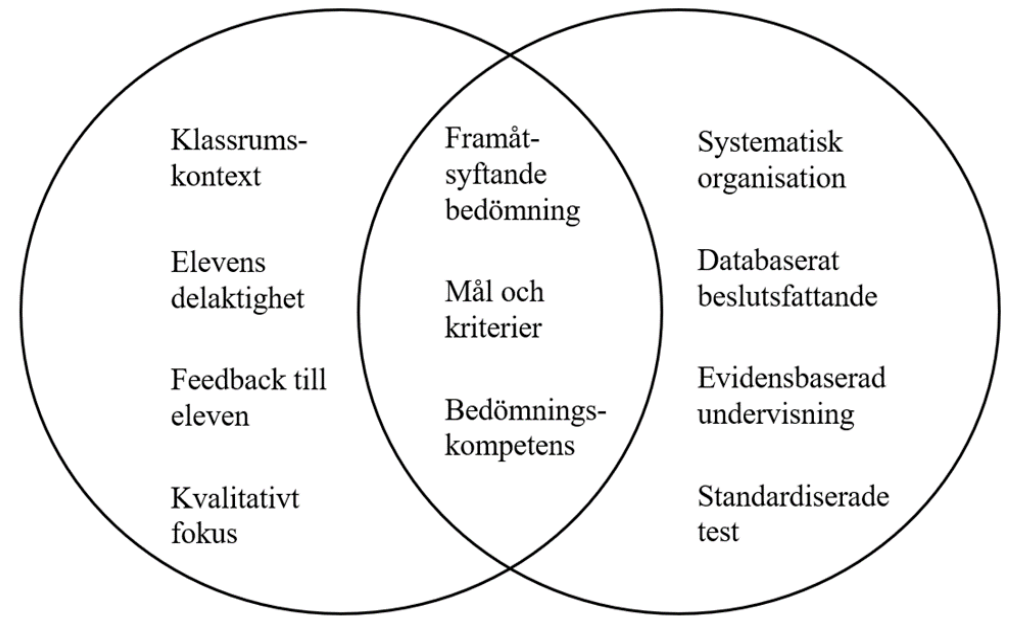

Figur 2. Venn-diagrammet illustrerar de unika nyckelaspekterna för formativ bedömning respektive RTI samt de viktiga aspekterna som de har gemensamt. (Egen översättning efter Andersson m.fl. 2019, s. 112).

Analysen visar att inom förhållningssätten formativ bedömning och RTI finns det både möjligheter och begränsningar. Oavsett om det är formativ bedömning eller RTI som används så krävs tid och energi av de inblandade.

Inom RTI har en asymmetrisk maktfördelning identifierats. För att hantera den föreslås en närmare interaktion mellan elever och lärare angående tolkningen av testresultat och förslag för framtida undervisning, menar vi. Resultaten visar att läraren fattar oräkneliga beslut om anpassningar varje dag. RTI kan bidra med mer systematiska metoder, inklusive dokumentation av elevernas framsteg i förhållande till olika undervisningsmål och syften. Från en pragmatisk synvinkel och utifrån perspektivet att elevernas lärande är det som är viktigt, så kan svaret på frågan om hur mycket eleverna behöver veta om mål variera mellan olika situationer. Vi hävdar att det är en empirisk snarare än en ideologisk fråga. I linje med Perrenoud (1991) argumenterar vi för en pragmatisk syn på formativ bedömning, RTI och andra framåtsyftande bedömningar, som inkluderar omfattande överväganden av bedömningsinformation för att anpassa undervisningen samt feedback som involverar elever i sitt eget lärande.

En annan slutsats är att hållbara, framåtsyftande bedömningar måste förankras i lärarnas yrkesetik samt bedömningskompetens. Kunskap om olika förhållningssätt för framåtsyftande bedömning kan underlätta professionell tillväxt och hjälpa till att förhindra att gamla vanor och 
traditioner medför onödiga begränsningar i arbetet med bedömning och undervisning i klassrummet. I vissa fall, då elever och lärare är belastade av allt för många bedömningar, kan en hållbar anpassning $\mathrm{i}$ ett klassrum innebära att minska antalet bedömningar och fokusera på andra aspekter av undervisningen. Vi menar att vad som faktiskt främjar elevernas lärande och välbefinnande borde vara de viktigaste frågorna när bedömning, oavsett typ, används. Att reflektera runt varje bedömnings konsekvenser är kärnan $\mathrm{i}$ en pragmatisk syn på framåtsyftande bedömning.

\section{Artikel II}

Nordström, T., Andersson, U. B., Fälth, L., \& Gustafson, S. (2019).

Teacher inquiry of using assessments and recommendations in teaching early reading. Studies in Educational Evaluation, 63, 9-16.

\section{Syfte}

Syftet var att bidra med kunskap om lågstadielärares användning av bedömningsinformation, inklusive undervisningsrekommendationer för att anpassa undervisningen efter elevernas individuella behov.

\section{Metod}

Fokusgruppsintervjuer genomfördes med åtta lärare, indelade i två grupper. Samtliga lärare arbetade med tidig läsutveckling i årskurs 1-3, men i olika skolor och alla lärare arbetade med LegiLexis verktyg för att stödja lärares arbete med läsutveckling. Resultaten analyserades med hjälp av tematisk analys (Braun \& Clarke, 2006).

\section{Resultat}

Analysen av lärarnas berättelser resulterade i tre teman: Medvetenhet om elevernas lärande; Förändringar i undervisningsorganisationen, men inte när det gäller individualiserat innehåll, och Stärkt lärarroll, men blygsam professionell utveckling.

Det första temat, Medvetenhet om elevernas lärande, visade att lärarna hade upptäckt och såg sina elevers läsutveckling mer detaljerat, de uttryckte att de nu såg kopplingen mellan elevernas läsutveckling och sin egen undervisning. Läraren hade blivit medveten om individuella behov, inklusive medvetenhet om hur olika elever utvecklar sina läsfärdigheter.

Det andra temat, Förändringar i undervisningen, men inte angående individualiserat innehåll, visade att lärarna var medvetna om hur man använder differentierad undervisning baserat på läsprofilerna och rekommendationerna. Detta inkluderade också att anpassningar av undervisningen gjordes i överensstämmelse med elevernas progression och användes för olika tillfälligt sammansatta elevgrupper. Lärarna 
uttryckte att de tog dessa överväganden på allvar, eftersom de betonade att ingen elev skulle behöva komma efter i läsutvecklingen. De anpassningar som beskrevs handlade främst om att dela in eleverna $\mathrm{i}$ läsgrupper och dela högläsningsbok för olika nivåer av läsförmåga. Undervisning som riktades mot individuella behov av enstaka läskomponenter (t.ex. ordigenkänningsövningar) var däremot inte framträdande i resultaten.

Det sista temat, Stärkt lärarroll, men blygsam professionell tillväxt, visade att lärarna uttryckte att de hade blivit stärkta i sin roll som lärare vilket påverkat till exempel kommunikationen med föräldrarna och med andra lärare i skolan. Dessutom visade resultaten att de hade påbörjat användningen av bedömningsverktyget och upplevde dess potential, till exempel genom mer utvecklat samarbete med kollegor om hur de kan förbättra undervisningen och hur resurser kan fördelas. Dessa beskrivningar, av möjliga användningsområden, men begränsad faktisk användning av bedömningarna kan anses tillhöra de inledande faserna för effektiv användning av elevdata. Resultaten ligger på så vis i linje med en tidigare studie (Lai \& McNaughton, 2016) om utmaningarna med att anpassa undervisningen med stöd av ett bedömningsverktyg med instruktioner. För att fullt ut kunna använda all tillgänglig bedömningsinformation och för lärares möjligheter och förmåga att stödja olika elevers individuella behov, krävs ytterligare implementering av verktyget.

\section{Artikel III}

Andersson, U. B., \& Löfgren, H. (under utgivning). Bedömningar för anpassning i tidig läsundervisning: Lärares erfarenheter av att utveckla elevers avkodningsförmåga. Pedagogisk forskning $i$ Sverige.

\section{Syfte}

Denna studies syfte var att bidra med kunskap om lärares arbete med att använda bedömningsinformation som underlag för anpassningar i läsundervisning med fokus på avkodning.

\section{Metod}

Vi studerade specifikt de bedömnings- och anpassningshandlingar lärare berättade att de gjorde och hur de motiverade dessa handlingar inom ramen för ett lokalt utvecklat läsprojekt (Träningslägret) för att höja elevers avkodningsförmåga.

I studien användes en narrativ metodansats (Goodson \& Sikes, 2001). Vi genomförde 12 individuella intervjuer med lärare som var engagerade i tidig läsundervisning från förskoleklass till årskurs 3. De deltagande lärarna arbetade på två olika skolor inom ett rektorsområde där alla klasser arbetade med att utveckla elevernas förmåga att avkoda 
med stöd av Träningslägret. Under intervjuerna uppmanades lärarna att berätta om sina erfarenheter av att arbeta med Träningslägret och gärna ge konkreta exempel. Intervjuerna analyserades med hjälp av narrativ analys (Labov \& Waletzky, 1967/1997).

\section{Resultat}

Studiens resultat presenteras i form av tre berättelser. Den första berättelsen, Att lyssna och utmana, fokuserar på kognitiva bedömnings- och anpassningsaspekter och en anpassningshandling som är inriktad på avkodningens kritiska aspekter. Den andra berättelsen, Att överväga och förenkla, fokuserar på lärarens sökande efter rätt anpassning. I berättelsen beskriver läraren såväl kognitiva som sociala bedömningsaspekter. Den tredje berättelsen, Att göra självständiga anpassningar, handlar om en utmanande undervisningssituation och om en anpassningshandling som går utanför projektets fastställda form. I denna berättelse framträder bedömnings- och anpassningsaspekter av kognitiv och social karaktär. Resultaten visar att lärarna använder en variation av såväl kognitivasom sociala bedömningsaspekter beaktas av lärarna när de anpassar avkodningsundervisningen. Att de kognitiva aspekterna bedöms ligger i linje med tidigare studier om avkodning (Fuchs \& Fuchs, 2006; Fälth \& Svensson., 2015). Att de sociala bedömningarna som handlar om interaktion, elevers beteende och känslor betonas i berättelserna var ett mer oväntat resultat eftersom de inte brukar fokuseras i sådana studier och inte heller i beskrivningen av Träningslägret. Ett viktigt bidrag från den här studien är således att de sociala bedömningarna som lärarna gjorde gavs stor betydelse för elevens avkodningsträning.

Träningslägret, betraktat som ett exempel på en praktik som en skola kan använda sig av för att stödja lärares arbete, synliggör behovet av ett professionellt handlingsutrymme för lärarna. Lärarna tänjer på ramarna för läsprojektet och gör åtskilliga egna överväganden baserade på informella bedömningar som leder till nya anpassningar. Dessa kan, enligt lärarna, ge högre precision än de standardiserade anpassningarna. En slutsats i artikeln är att det är väsentligt att lärare får möjlighet att göra förfinade och historiskt förankrade bedömningar för att läsprojekt av den här typen ska bli framgångsrika och leda till läsutveckling.

Att skaffa sig professionellt handlingsutrymme ställer krav på ämneskunskaper och didaktisk förmåga, men också krav på självreflektion, omdöme och yrkesetiskt förhållningssätt. En slutsats är att dessa kompetenser är viktiga eftersom de kan bidra till att läraren utvecklar en balans där hänsyn tas till elevens behov på kort- och lång sikt och mellan interna och externa förväntningar $i$ sin bedömningspraktik. 


\section{Artikel IV}

Andersson, U. B., Danielsson, H., Nordström, T., Fälth, L., \& Gustafson, S (inskickad). Effects of a forward-looking assessment tool with provided recommendations for teachers in early reading instruction.

\section{Syfte}

Det övergripande syftet med artikeln var att bidra med kunskap om effekterna av att använda ett bedömningsverktyg som gav rekommendationer för tidig läsundervisning, samt kunskap om variation bland elever som initialt var svaga avkodare och deras läsutveckling $\mathrm{i}$ årskurs 1 . Vi avsåg att undersöka skillnader mellan svaga avkodare som var föremål för en avkodningsrekommendation efter det första testtillfället, förbättrade sin avkodning och sedan fick en annan rekommendation (Responders) och svaga avkodare som utvecklade sin avkodning långsammare och fick en avkodningsrekommendation efter både det första och andra testtillfället (Non-responders).

\section{Metod}

Studien baserades på en 3 x 3 mixed design med den oberoende mellangruppsvariabeln grupp (Responders, Non-responders) och den oberoende inomgruppsvariabeln testtillfälle (T1, T2 och T3) och åtta olika läsrelaterade förmågor som beroende variabler. För att analysera resultaten användes beskrivande statistik och variansanalys. Vi skapade två grupper baserat på elevernas testresultat vid testtillfälle 1 och 2: Non-responders (2075 elever) och Responders (674 elever). Gruppen Non-responders fick en avkodningsrekommendation efter både höst- (T1) och vintertestningen (T2). Gruppen Responders fick en avkodningsrekommendation efter hösttestningen och en annan rekommendation (som inte var avkodning) efter vintertestningen.

Vi samlade också in data om elever som fungerade som en jämförelsegrupp (71 elever). Jämförelsegruppen testades med LegiLexis test men fick inga rekommendationer baserat på sina resultat.

\section{Resultat}

Av de elever vars data passerade vår kvalitetskontroll fick 55,9\% en avkodningsrekommendation vid $\mathrm{T} 1,47,3 \%$ vid $\mathrm{T} 2$ och $37,1 \%$ vid $\mathrm{T} 3$.

Resultaten av variansanalyserna visade att det fanns en signifikant huvudeffekt av testtillfälle för samtliga åtta läsrelaterade förmågor. Resultaten visade också att det fanns en signifikant huvudeffekt av grupp på samtliga test. Gruppen Non-Responders presterade lägre än grupperna Responders och jämförelsegruppen på samtliga test. De 
viktigaste resultaten var interaktionseffekterna eftersom de visade om någon grupp utvecklades mer än någon annan grupp. Resultaten av variansanalysen visade att det fanns en signifikant interaktionseffekt för samtliga förmågor utom ordkunskap och hörförståelse.

Gruppen Responders kännetecknades av inledande ordavkodningsproblem men en avsevärd förbättring mellan de tre testtillfällena, vilket ledde till en högre läsförståelse i slutet av årskurs 1. Deras avkodning förbättrades mest när denna färdighet var det rekommenderade fokusområdet för undervisningen, men deras läsförståelse förbättrades stadigt också när rekommendationerna ändrades.

Lärarnas användning av LegiLexi-verktygets rekommendationer kunde till viss del ses genom att studera de olika utvecklingskurvorna (jfr Figur 1-4). Det verkade också som att deras användning bidrog till en positiv läsutveckling för de 674 elever som tillhörde gruppen Responders. Gruppen Non-responders, vars lässvårigheter kvarstod även i slutet av årskurs 1 , var mer än tre gånger så stor som Responders-gruppen. De låga resultaten vid testtillfälle 3 (i slutet av årskurs 1) indikerade att en betydande andel av eleverna i gruppen Non-responders skulle få fortsatt undervisningsrekommendation med fokus på avkodning även nästföljande termin i årskurs 2. Detta indikerade att rekommendationen att fokusera på avkodning inte var tillräcklig för den stora gruppen av Non-responders. Även om elevernas resultat visade en viss utveckling, fanns en risk att läsutvecklingen skulle bli för långsam för att denna grupp skulle nå de svenska nationella målen för läsförståelse (Skolverket, 2019) under sin tid i lågstadiet. För dessa tidiga läsare som har svårt att lära sig läsa kvarstår frågan om hur undervisningen kan anpassas för att gynna deras läsutveckling mest. Vi menar att dessa elevers behov bör utvärderas regelbundet och att resultaten av undervisningen behöver utvärderas kontinuerligt under årskurs 1-3. 


\section{Diskussion}

I följande kapitel diskuterar jag avhandlingens resultat och besvarar avhandlingens forskningsfrågor med utgångspunkt i följande rubriker: "Bedömningar för att identifiera elevers behov och anpassa undervisningen", "Den professionella läraren och stödverktyget" och "Eleven som facit". De tre rubrikerna är i hög grad kopplade till mina tre forskningsfrågor och följer den ordningen. Den första rubriken har ett vidare perspektiv och inkluderar samtliga artiklar I-IV.

\section{Bedömningar för att identifiera elevers behov och anpassa undervisningen}

I avhandlingens artiklar framträder en rad olika användningsområden för den framåtsyftande bedömningen, till exempel för att anpassa undervisningen, för att få bekräftelse på tidigare kunskaper om elevens behov och för att få mer information. I det följande kommer avhandlingens första forskningsfråga att diskuteras. Den handlar om hur lärares användning av framåtsyftande bedömning i tidig läsutveckling kan ta sig i uttryck i teori och praktik.

I avhandlingens tre empiriska artiklar används the Simple View of Reading för att förklara läsningens två grundläggande komponenter avkodning och språkförståelse, och dessas betydelse i den tidiga läsundervisningen (Gough \& Tunmer, 1986; Gustafson m.fl., 2013). Båda komponenterna anses vara nödvändiga för att uppnå god läsförståelse och kan användas för att förklara skillnader i elevens läsutveckling (Gough \& Tunmer, 1986; Lonigan m.fl., 2018).

I den tidiga läsutvecklingen är avkodningen central. Typisk avkodningsutveckling kan delas in i faserna pseudoläsning, logografisk läsning, fonologisk och ortografisk-morfemisk läsning (Høien \& Lundberg, 2013). Undervisningen behöver anpassas till var eleven befinner sig i denna utveckling.

I lärarnas arbete med att anpassa sin undervisning syns den framåtsyftande funktionen som kännetecknar formativ bedömning och RTI i Artikel III. Där beskriver de sin användning av detaljerad bedömningsinformation för att anpassa avkodningsträningen.

"[...] när jag hör, när jag lyssnar på eleverna då märker jag ju att de fastnar ju oftast på de här STRRR, och då är det ju de orden som vi ska ta oss förbi för att öka flytet. Så att så, så har jag gått till väga. Sedan har jag elever som växlar vokaler, att man känner inte skillnaden på U och $\mathrm{Y}$ till exempel, eller E och I, då har jag tagit sådana ord där 
man verkligen måste anstränga sig för att se vilken vokal det är.” (Artikel III, lärare årskurs 3).

Av lärarens berättelse framgår att bedömningsinformationen används för att skräddarsy träningsuppgifter där eleven får träna på sina specifika svårigheter i syfte att utveckla ortografisk avkodning och läsflyt. Färdighetsträning för att utveckla ortografisk läsning förespråkas av Høien och Lundberg (2013). De menar dock att det finns en risk att en alltför ensidig träning kan få eleven att tappa läsmotivationen. Hur undervisningen genomförs för att motverka detta är med andra ord en viktig aspekt som också syns i lärarnas berättelser på olika vis.

Ett exempel på hur lärarna använder bedömning i syfte att stimulera elevens läsmotivation är med hjälp av återkommande testresultat. Dessa används tillsammans med eleven för att synliggöra elevens egen utveckling, men också för att locka till ytterligare avkodningsträning (Artikel II). Kopplingen som beskrivs mellan elevens motivation att lära och metakognition är kännetecknande för formativ bedömning (se artikel 1). Genom att få syn på sitt eget lärande ska eleven lära sig att lära (Wiliam, 2011). I Artikel I framhåller vi att lärarens kunskap om sina elevers individuella behov har en avgörande betydelse $\mathrm{i}$ sammanhanget, inte minst ur ett hållbarhetsperspektiv. Det är inte självklart att alla elever tilltalas eller motiveras av uppmaningen att träna lite till (Perrenoud, 1991). För att undvika misstaget att ställa krav som kan leda till motsatt effekt, det vill säga att eleven förlorar motivation, kan sociala bedömningsaspekter utgöra ett viktigt komplement till bedömning av testresultaten (Artikel III).

För att den formativa bedömningen ska fungera behöver både lärare och elever vara väl förtrogna med den formativa bedömningspraktiken (Black \& Wiliam, 2018; Perrenoud, 1991). Eleverna behöver utbildas i hur de ska använda mål i undervisningen men också i sina egna inlärningsprocesser. Det ställer krav på elevernas engagemang och motivation, som förstås kan variera i ett klassrum. Elevernas behov av vägledning kräver att läraren besitter förmågan att involvera och aktivera dem i både den formativa bedömningspraktiken och i deras egna lärande (Perrenoud, 1991).

I flera andra berättelser syns exempel på hur lärarna använder bedömningsinformation baserat på såväl sociala som kognitiva bedömningsaspekter för att organisera anpassningar av undervisningen. I dessa anpassningar ges kommunikation och interaktion mellan elever och mellan elever och lärare en betydande roll. I Artikel II beskrivs en anpassning som innebär att organisera läsgrupper i syfte att utveckla elevernas läsflyt eller läsförståelse. Läsgrupperna kan ses som ett led i att förbättra undervisningen. I Artikel III handlar det om att sätta samman fungerande elevpar för att de tillsammans ska bidra till gemensam och individuell 
avkodningsutveckling. Organisationen som innebär att eleverna parläser högt för varandra syftar också till att underlätta lärarens bedömningsarbete, genom att elever aktiveras under tiden som läraren kan ägna sig åt att bedöma enskilda elevers läsning.

Det framgår av resultaten i Artikel III att lärarna använder och gör överväganden om hur undervisningen ska anpassas baserat på å ena sidan kognitiva bedömningsaspekter, som testresultat och läsnivåer, och å andra sidan på sociala bedömningsaspekter. De sociala aspekterna kan till exempel handla om elevernas inbördes relation till varandra. Dessa bedömningsaspekter uppmärksammas i tidigare forskning om klassrumsbedömning (jfr Heritage, 2013; McMillan, 2017). Ett annat resultat från Artikel III är att de sociala bedömningarna ges en oväntat stor betydelse för hur avkodningsundervisningen anpassas. Det är intressant eftersom elevers testresultat är mer konkreta än sociala aspekter som inte ens har bedömts på ett systematiskt sätt (jfr Andersson, 2021).

Resultaten i Artikel II uttrycker att lärarna har blivit mer medvetna om sina elevers lärande $\mathrm{i}$ relation till målen $\mathrm{i}$ ämnet. Bedömningsinformationen som verktyget erbjuder $i$ form av testresultat och rekommendationer används i nedanstående berättelse framför allt för att identifiera elevers olika behov och följa upp undervisningens resultat (Artikel II). I ett citat framhåller läraren betydelsen av att få bekräftelse på att undervisningen givit önskat resultat. Hon kan slappna av när testresultaten ligger i linje med målnivåerna.

"Det har verkligen varit informerande att ha tillgång till målnivåerna mellan testtillfällen, särskilt eftersom jag har elever som har svårt att lära sig att läsa. Efter den andra bedömningen visade det sig att de har förbättrat sina poäng på ordförråd och språkförståelse. Då kan du andas ut och veta att eleverna är på gång". (Egen översättning Artikel II, lärare A, s. 14.).

Återkommande och systematisk bedömningsinformation i form av testresultat kopplat till målnivåer ges i lärarens berättelse en utvärderande funktion, både vad gäller elevens läsutveckling och lärarens undervisning. Berättelsen visar på lärarens behov av att stanna upp, reflektera bakåt och utvärdera också i en bedömningspraktik där rörelsen framåt är central. Detta kan vara nog så viktigt, inte minst ur ett hållbarhetsperspektiv (Hirsh \& Lundahl, 2021). Visionen om det livslånga lärandet kan få vilken lärare eller elev som helst att tappa sugen om det innebär att aldrig får stanna upp och beundra utsikten av det som lärts.

Inom RTI är en tillbakablickande funktion kopplad till mål och kriterier inbyggd i systemet, till skillnad från $i$ formativ 
bedömningspraxis där "här och nu" i relation till undervisningens mål är mer framträdande (se Artikel 1). För att en tillbakablick ska vara möjlig krävs någon form av historisk dokumentation. Den kvantitativa formen som läraren i citatet syftar på kan underlätta en sådan tillbakablick, men skulle i linje med resultaten i Artikel III behöva kompletteras med information av mer social karaktär för att bidra till att utveckla en mer hållbar bedömningspraktik.

Begreppet hållbar bedömning kan tolkas och förstås på olika vis (Hirsh \& Lundahl, 2021; Pope m.fl., 2004). Boud och Soler (2016) använder begreppet hållbara bedömningar för att belysa det livslånga lärandet och bedömningarnas påverkan på eleven. Gardner (2012) kopplar hållbarhet till implementering av formativ bedömning och menar att ett hållbart implementeringsarbete bygger på professionellt lärande, snarare än på ett ensidigt bruk av metoder. I avhandlingen handlar begreppet hållbara bedömningar om olika bedömningars användbarhet för att utveckla undervisningen och elevers läsförmåga, på kort och lång sikt (Andersson, 2021; Gardner , 2012; Levin, 2013).

Resultaten i Artikel IV bygger, i linje med RTI, på återkommande testning (Fuchs \& Fuchs, 2006). Resultaten visade hur eleverna utvecklade olika läsförmågor under årskurs 1 . Under tiden hade deras lärare fått undervisningsrekommendationer baserade på testresultaten från åtta olika lästest som samlades in vid tre olika testtillfällen. Informationen som lärarna hade att tillgå bestod dels av testresultat från fonologisk medvetenhet, bokstavskunskap, ordförståelse, hörförståelse, grundläggande läsförståelse, avancerad läsförståelse, ordavkodning och avkodning av pseudo-ord, dels av en undervisningsrekommendation. Undervisningsrekommendationen hade formen av ett fokusområde för tiden fram till påföljande testtillfälle. Resultaten visade hur elevernas utvecklingskurvor skiljde sig åt mellan den elevgrupp som hade lätt för att lära sig att läsa (Responders), den grupp som hade svårt att lära sig läsa (Non-responders), och jämförelsegruppen. Mönstren i resultaten antydde att lärarna hade använt sig av rekommendationerna eftersom elevernas läsutveckling i viss utsträckning överensstämde med den rekommendation som deras lärare fick.

I Artikel IV belyses vikten av avkodningskomponenten på så sätt att många elever verkade ha behov av avkodningsträning under hela årskurs 1. Det verkade inte som att en avkodningsrekommendation var tillräcklig för att de flesta av eleverna som hade svårt för att avkoda skulle utveckla sin läsning (Non-responders).

I det ovanstående framträder lärarnas användning av framåtsyftande bedömning $\mathrm{i}$ teori och praktik. Det framgår att lärarna använder bedömningarna för att både bekräfta sin tidigare kunskap om elevens behov och för att fylla på med ny information. 


\section{Den professionella läraren och stödverktyget}

Den andra forskningsfrågan gäller vilka professionella överväganden som framträder som betydelsefulla i lärarnas berättelser om att använda bedömning för att anpassa läsundervisningen inom ramen för ett lärarverktyg. Under denna rubrik kommer lärarnas erfarenheter av att använda ett bedömningsverktyg belysas och kopplas till lärares professionalism.

I likhet med LegiLexi har Träningslägret utvecklats utifrån ett identifierat behov av insatser för att elever ska lära sig att läsa i skolan. Eftersom elevernas behov på ett eller annat vis har tolkats som att lärarna behöver stöd riktas uppmärksamheten till läraren. Vid en jämförelse mellan verktygen framträder skillnader som Träningslägrets lokala förankring i kontrast till LegiLexis nationella utbredning. Träningslägrets obligatoriska deltagande med en fastställd arbetsgång, uttalat undervisningsinnehåll och färdiga metoder skiljer sig från LegiLexis verktyg som Sveriges lärare själva väljer att använda och som till skillnad från Träningslägret inte ger några specifika metodinstruktioner utan i stället rekommenderar ett fokusområde för läsundervisningen.

Resultaten i Artikel III, som handlar om Träningslägret, visar att lärarna tar stöd av verktyget på ett generellt plan. Tillsammans med sina elever deltar de i Träningslägret, men sättet som de är med på innebär att både följa och att tänja på de fastslagna riktlinjerna. Det betyder att lärarna fattar egna beslut som kan leda till att de förespråkade metoderna för enskilda elever modifieras. Det förefaller däremot som målet och syftet med Träningslägret står fast. Lärarens professionella överväganden i Träningslägerkontexten grundas på detaljer som fångas upp i stunden. Det handlar till exempel om att en elev har svårt för konsonantkoppling, en annan elev har svårt för vokaler, att ett elevpar inte agerar som de brukar, eller att en elev inte vill vara med. Lärarens professionella radar uppmärksammar olika händelser varav flera kanske inte skulle kopplas till avkodningsträning av en utomstående.

God läsundervisning ställer alltså höga krav på lärarens förmåga att bedöma elevernas läsutveckling, identifiera elevernas behov och att systematiskt och strukturerat anpassa klassrumsundervisningen med vägledning av den insamlade bedömningsinformationen (Adams, 1990; Alatalo, 2011). I avhandlingens fyra artiklar, liksom i tidigare forskning, belyses betydelsen av att tidigt identifiera och anpassa undervisningen efter elevens olika behov för att minimera risken att någon elev halkar efter och utvecklar bestående lässvårigheter (Catts m.fl., 2016; Snow, 1998).

Av resultaten i Artikel III framgår att det handlar om sociala och kognitiva bedömningsaspekter som av läraren bedöms som väsentliga för att eleven ska utveckla sin avkodning. Detaljerna som läraren 
uppmärksammat bedöms, övervägs och används för att anpassa undervisningen och för att motivera besluten som fattas. Dessa förfinade bedömningar och skräddarsydda anpassningar som vid behov sträcker sig bortom Träningslägerstrukturen menar jag är av särskilt intresse för att det visar ett professionellt snarare än instrumentellt förhållningssätt till bedömningsverktyget.

I Artikel II, där lärarna själva hade valt att använda LegiLexis verktyg fanns inte samma krav på att vara lojal mot ett överordnat beslut (jfr Artikel III). De hade själva valt att använda verktyget och var ofta ensamma eller få användare på samma skola. Av resultaten framgår att de såg verktygets potential, trots att de inte använde bedömningsinformationen som erbjöds fullt ut. Den användes för att organisera läsgrupper men inte för att individanpassa undervisningen. Intressant är emellertid att de beskrev hur de använde testresultaten i mötet med föräldrar.

\begin{abstract}
"Att använda de återkommande bedömningarna stärker min lärarroll när jag berättar för föräldrarna om deras barns läsutveckling. Det ger föräldrarna en känsla av trygghet. De bevittnar progression, även om de är oroliga”. (Egen översättning. Artikel II, lärare B, s14.).
\end{abstract}

Testresultaten användes för att styrka den egna yrkesrollen, berättade lärarna. Det signalerar, menade vi, ett behov av att stärka sin roll som lärare. Med stöd av testresultat och tydliga siffror, kan läraren styrka sin bedömning och framstå som professionell. Det verkar alltså som om lärarna plockar russinen ur kakan när de använde LegiLexis verktyg. Detta skulle också kunna tolkas som en professionell användning av ett bedömningsverktyg, i relation till den övriga undervisningskontexten (Biesta m.fl., 2015).

I motsats till ovanstående förefaller det som om lärarna ibland använde LegiLexis verktyg mer instrumentellt, det vill säga att fokus låg på att följa instruktionerna och låta eleverna genomföra hela testbatteriet. Därefter valde lärarna i Artikel II att använda en begränsad del av den bedömningsinformation som erbjöds. Det är rimligt att anta att detta leder till att verktygets funktion som stöd till läraren åtminstone delvis går förlorad.

En annan förklaring till de val som lärarna gör är att de är relativt nya användare. Lärarna har just påbörjat sin förståelse för hur verktyget kan användas. Till skillnad från RTI, där evidensbaserade interventioner för att träna specifika förmågor används (se Artikel 1), ger LegiLexis verktyg inga färdiga lektionsplaneringar. Det är lärarens uppgift och ansvar att själv anpassa undervisningen utifrån rekommenderat fokusområde (Artikel II \& IV).

Tidigare studier visar att lärarnas kompetens och professionella utveckling påverkar hur verktyget används. Om teoretisk kunskap och 
praktisk förståelse om formativ bedömning saknas ökar risken för att metoder snarare än förhållningssätt fokuseras (Birenbaum m.fl., 2011; van den Hurk m.fl., 2016). Resultaten i Artikel II ligger i linje med Moats (2009) som lyfter fram lärarverktygs begränsade möjligheter att ersätta den skickliga läraren.

Behovet av vägledning antyds i lärarnas berättelser, bland annat då de eftersöker ett ökat samarbete med kollegor för att utbyta erfarenheter och tolka bedömningsinformation. Det verkar som att verktygets funktion som stöd och kompetensutveckling för den enskilda läraren inte är självklar den första tiden och att lärarna behöver lära sig hur verktyget fungerar. Det låter rimligt och professionellt att ägna tid åt att sätta sig in i nya till exempel bedömningsverktyg innan de tas i bruk och ska användas fullt ut. En fråga som bör ställas och besvaras i den aktuella skolpraktiken innan det fattas beslut om huruvida ett lärarverktyg ska användas eller ej är vilka insatser som krävs för att användandet ska fungera i lärarens klassrum. Det är en fråga som lärare och rektor med fördel kan finna svar på tillsammans menar jag. I beslutet bör hänsyn tas till vilka andra bedömningar som görs i klassrummet med tanke på att uppnå en hållbar bedömningspraktik (Andersson, 2021).

Bedömningsinformation som samlas in och inte används, eller används i begränsad utsträckning, framstår för mig som ett resursslöseri som borde undvikas. Ur ett lärarperspektiv finns det knappas utrymme för att lägga tid och energi på lästest om resultaten inte kan användas. Detsamma gäller i än högre grad för den unga eleven som ju är den som gör den verkligt stora insatsen, i värsta fall till ingen nytta alls (jfr Hirsh, 2020).

Tidigare studier visar att det kan ta många år att utveckla lärares yrkeskompetens (Colnerud \& Granström, 2015; van den Hurk m.fl., 2016). Hur lärarens yrkeskompetens utvecklas kan kopplas till vilket stöd läraren får. Stöd i analysarbetet så att bedömningsinformation kan användas för att anpassa undervisningen är en aspekt som påverkar lärarens utveckling positivt (van den Hurk m.fl., 2016).

Till skillnad från Träningslägret saknar LegiLexis verktyg den lokala förankringen med allt vad det innebär av stöd, sammanhang och kontextuell förförståelse. I linje med Hirsh med flera (2020) visar resultaten i Artikel II och III på kontextens betydelse för hur en metod kan tas emot och tas omhand, det vill säga användas för att bidra med det som var avsikten från början.

Det förefaller som att LegiLexis verktyg har en design som förutsätter en professionell lärare. Det vill säga en lärare som använder sig av ämneskompetens och didaktisk förmåga för att fatta reflekterade beslut om lämpligt val av undervisningsmetod. För den intresserade läraren fanns möjlighet att söka kunskap $i$ ett nätbaserat inspirationsbibliotek samt en övningsbank. I vilken omfattning lärarna 
använde dessa kompletterande stöd framgår inte av vår studie (Artikel II).

Resultaten i Artikel III visar att Träningslägret på sätt och vis är LegiLexi verktygets motsats. Det mesta kan tyckas vara färdigtänkt och läraren förväntas följa ett bestämt upplägg eller träningsschema. Lärarens roll och ansvar i Träningslägret påminner på så vis om RTI där det mesta är förutbestämt (Artikel I). Resultaten i Artikel III visar dock att lärarnas möte med Träningslägret leder till att de tydligt uttalade ramarna tänjs. Dessa ramar utgörs av för lärarna relativt kända metoder för att träna avkodning och det är först då dessa inte fyller sin funktion som lärarna med stöd av professionella överväganden tar det handlingsutrymme som de behöver. De använder verktyget utifrån sina givna, kontextuella förutsättningar, vilket naturligtvis även lärarna i Artikel II gör.

Mot bakgrund av ovanstående framträder kontexten, det specifika sammanhanget som verktyget ska användas $i$, som betydelsefull för i vilken utsträckning det kan användas av läraren på ett sådant vis att det bidrar till elevernas läsutveckling på kort och lång sikt. För att underlätta implementering och användning av lärarverktyg i tidig läsundervisning menar jag i likhet med Hirsh (2020) att det väsentliga inte är att hitta generella lösningar som passar för alla. Det är i stället att uppmärksamma de förutsättningar och möjligheter som varje lärare har och utifrån detta organisera så att ett ömsesidigt och hållbart utbyte uppstår mellan läraren, eleven och verktyget.

\section{Eleven som facit}

Forskningsfråga c handlar om vilka effekter lärarnas användning av bedömningsverktyg kan ha på elevers tidiga läsutveckling. I nedanstående text kommer jag att beskriva och diskutera resultat som handlar om elevernas läsutveckling över tid.

Det tydligaste kunskapsbidraget i relation till forskningsfråga $\mathrm{c}$ kommer ifrån Artikel IV. I artikeln beskrivs och analyseras testresultat från 2749 elever från 200 medverkande klasser. Resultaten visade att det fanns en signifikant huvudeffekt av grupp på samtliga test utom för gruppen Responders (elever som lär sig att avkoda relativt enkelt) som presterade högre än grupperna Non-Responders (elever som har avkoda för att lära sig läsa) och jämförelsegruppen.

Det fanns också statistiskt signifikanta huvudeffekter av testtillfälle för alla åtta testerna. Alla tre grupperna förbättrades över tid. Det fanns statistiskt signifikanta interaktioner mellan grupp- och testtillfälle för lästesten Fonologisk medvetenhet, bokstavskunskap, ordförståelse, hörförståelse, grundläggande läsförståelse, avancerad läsförståelse, ordavkodning och avkodning av pseudo-ord. Det fanns inga statistiskt signifikanta interaktioner för ordförståelse och hörförståelse. 
I Artikel IV ser vi hur eleverna utvecklat olika läsförmågor under årskurs 1 samtidigt som deras lärare erhöll rekommendationer om undervisningsfokus. Däremot lämnades lärarna fria att använda bedömningsinformationen som de fann lämpligt i sina respektive klassrum. Studien fokuserade på de elever som hade en låg avkodningsförmåga när de började första klass. Resultaten visade att en tredjedel av eleverna (Responders) utvecklades så mycket att deras lärare fick rekommendationen att byta undervisningsfokus efter det andra testtillfället på vintern under årskurs 1. Två tredjedelar av eleverna (Non-responders) visade på väsentligt lägre progression och deras lärare fick rekommendationen att fokusera på avkodning även efter det andra testtillfället i årskurs 1. Effekterna av lärarnas användning av bedömningsverktyget illustrerades med utvecklingskurvor där Responders, Non-responders och jämförelsegruppen jämförs över tid.

I linje med tidigare forskning (t.ex. Adams, 1990; Ehri, 2020), tyder resultaten i denna studie på att det främst är ordavkodning som signalerar kritiska skillnader i tidig läsutveckling. En slutsats med ledning av detta är att bedömningsverktyg som används under de första årskurserna i skolans läsundervisning med fördel kan ge information om avkodningsförmågor.

Som grund för rekommendationerna som gavs i Artikel IV användes kvantitativa testresultat. Inom forskning som rör formativ bedömning har test ibland förknippats med summativ bedömning och därmed även med betyg, sortering och identitetsskapande (Korp, 2011). Av Artikel I framgår att detta kan ha bidragit till att standardiserade test och användningen av kvantitativa data använts $i$ begränsad utsträckning inom formativ bedömning, även om det inte var avsikten från början (Black m.fl., 2004). Inom formativ bedömning har fokus i stället legat på användningen av kvalitativa bedömningar och metoder för att ge återkoppling till eleven (Artikel 1). Jag menar att både kvantitativ och kvalitativ information kan användas i syfte att anpassa läsundervisning. En ensidig användning av någon av formerna kan ses som en onödig begränsning inom såväl forskning som bedömningspraktik (se artikel 1). Skillnaden mellan kvantitativ och kvalitativ information hänvisar bara till formen och inte nödvändigtvis till syftet med bedömningarna. Inom RTI, som i likhet med formativ bedömning används för framåtsyftande ändamål, används till exempel främst standardiserade test för att samla in bedömningsunderlag och anpassa undervisningen (Fuchs \& Fuchs, 2006).

LegiLexis verktyg (Artikel IV) fokuserar på färdigheter och förmågor som är relativt enkla att mäta kvantitativt. Testresultaten kan användas för att bedöma kvantitativa framsteg genom att vid olika mättillfällen analysera resultat från samma test. Avsikten är att följa elevernas utveckling över tid och genom upprepad testning utvärdera 
och anpassa undervisningen med ledning av elevernas testresultat, i linje med RTI (Fuchs \& Fuchs, 2006; Vaughn \& Fuchs, 2003).

Även om eleven är facit så kan inte till exempel ett testresultat tolkas som att det med säkerhet överensstämmer med elevens verkliga förmåga. När bedömningsinformation tolkas och används måste hänsyn tas till olika aspekter kopplade till den metod eller det specifika test som används (jfr Keenan m.fl., 2008; Keenan \& Meenan, 2014). Metodens eller testets tillförlitlighet (reliabilitet) i sig är väsentlig liksom de förutsättningar som råder under själva bedömningssituationen, det vill säga att om en lågstadieelev av en eller annan anledning (kanske för att det kryper en myra på bänken) blir distraherad kan det påverka elevens läsresultat, oberoende av bedömningsform. Det handlar alltså om att inte bli för instrumentell eller närsynt i sin bedömning utan att tänka på det långsiktiga, hållbara, målet för läsundervisningen.

I Artikel I använder vi begreppet hållbarhet och syftar då på bedömningspraktiken placerad i en större kontext där andra aspekter av läsundervisningen kan vara nog så viktiga. Allt handlar inte om bedömning, men det går inte att komma ifrån att den är central i tidig läsundervisning. Vad läraren gör är viktigt oavsett vilken metod eller vilket verktyg som används. Avhandlingen bidrar med kunskap genom att belysa vikten av att följa elever över tid och använda olika typer av bedömningsinformation för att anpassa undervisningen till den enskilda individen. Eleven är facit på hur effektiv läsundervisningen har varit, vilket kan visas i testresultat, men för att denna utveckling ska vara hållbar behöver även hänsyn tas till elevens motivation och välmående.

\section{Avhandlingens begränsningar och styrkor}

Avhandlingen har en relativt tydlig ram; den handlar om hur lärare kan använda och använder framåtsyftande bedömning i tidig läsutveckling. Det är, menar jag, en avgränsad och specifik kontext. I ett tidigt skede av avhandlingsarbetet fanns en plan på att studera lärares bedömning $\mathrm{i}$ både förskola och årskurs $\mathrm{F}-3$, men förskolan valdes bort för att avgränsa avhandlingen. Däremot har jag valt att använda flera olika teoretiska perspektiv och metoder för datainsamling och analys.

Mitt val att använda både kvalitativ och kvantitativ metod har inneburit en del utmaningar. Det har till exempel inneburit att jag i stället för att lära mig en enda metod fått sätta mig in i flera med allt vad det förde med sig av krav på bland annat begreppsförståelse (Creswell \& Creswell, 2017). Det kan ha krävt mer energi och ansträngning, och tagit längre tid, än om jag valt att använda samma datainsamlingsmetod och analysförfarande i samtliga studier och artiklar. 
Arbetet med kvantitativ metod och analys i Artikel IV har jag upplevt som den största utmaningen. Det beror på att det kvantitativa forskningsfältet var nytt för mig, både vad gäller begrepp och praktiskt genomförande. Jag har haft möjlighet att ta stöd av medförfattare och påbörja ett lärande inom det kvantitativa fältet som jag har tagit vara på. Det som framför allt motiverade valet att använda kvantitativ metod var dess lämplighet för att besvara frågor om effekter, som de i Artikel IV. Jag ser det också som viktigt att studera hur lärares användning av ett bedömningsverktyg kan påverka läsutveckling hos elever. Metodvalet för Artikel IV ligger på så vis i linje med pragmatismens intresse för mål och praktisk nytta på flera plan (Feilzer, 2010).

I Artikel II och III valde vi intervju som datainsamlingsmetod, fokusgrupp för att ta del av lärares diskussioner och narrativ intervju för att ta del av lärares reflekterade erfarenheter om sitt arbete med bedömning. Inför besluten som handlade om datainsamlingsmetod övervägde vi möjligheten att göra en observationsstudie, men valde bort det alternativet till förmån för intervjuer. I en avhandling som handlar om hur lärare använder bedömning kan det ses som en begräsning att inte ha studerat lärarens görande i praktiken, men intervjuerna gav oss möjlighet att ta del av lärarnas beskrivningar, förklaringar och motiveringar och bidrog på så vis med användbar information. Det var just denna möjlighet att ta del av lärares diskussioner och motiveringar som avgjorde metodvalen.

Avhandlingens bidrag när det gäller lärares användning av bedömningar visar bland annat att både sociala och kognitiva bedömningsaspekter har betydelse för hur undervisningen anpassas i syfte att utveckla elevens läsförmågor. Detta perspektiv som belyser kopplingen mellan bedömning, avkodning och undervisning ser jag som en av avhandlingens styrkor. Detta kan sägas handla om lärares professionella användning av bedömningsinformation $\mathrm{i}$ tidig läsundervisning.

Sedan studierna i Artikel II och IV gjordes har LegiLexis verktyg utvecklats vad gäller testbatteri, inspirationsbibliotek och övningsbank. Vid tiden för datainsamlingen $i$ studierna var inte inspirationsbiblioteket och övningsbanken så utvecklade. Idag används verktyget av 21000 lärare spridda över hela landet, som tillsammans med forskare och stiftelsens ledning fortsätter att utveckla verktyget. 


\section{Slutsatser och pedagogiska implikationer}

Som framgår av Artikel I har både formativ bedömning och RTI sina begränsningar. Samtidigt gäller det att ta vara på möjligheterna som finns inom respektive pedagogiskt förhållningssätt. Framåtsyftande bedömningar är ett mer generellt begrepp och skulle kunna användas som ett alternativ till formativ bedömning och RTI om inte något mer specifikt i respektive begrepp avses. Begreppen formativ bedömning och RTI har specifika innebörder som först blir tydliga när de ställs mot varandra. En lärare som bara har kunskap om ett av begreppen, formativ bedömning eller RTI, är mer begränsad och har inte samma möjligheter som en lärare med bredare teoretiska kunskaper. På detta sätt hänger teori och praktik ihop när det gäller framåtsyftande bedömningar i tidig läsundervisning.

En utmaning för forskare och lärare som arbetar med formativ bedömning är att det ska bli hållbart på lång sikt och att det resurskrävande bedömningsarbetet verkligen ska göra nytta, det vill säga resultera i att eleverna lär sig att läsa och utvecklar motivation till läsning. De båda verktyg som beskrivs och analyseras i denna avhandling behöver integreras med övrig verksamhet i klassrummet. I denna verksamhet ingår andra bedömningar som är obligatoriska i svensk skola.

När lärare använder bedömningsverktyg aktualiseras frågan om lärares professionalism. Hur stort utrymme lärarna har och bör ha för att göra egna anpassningar inom ett område kan variera men det är en viktig fråga där den aktuella kontexten utgör ett viktigt perspektiv.

Att genomföra lästest men sedan inte använda den bedömningsinformationen som blir tillgänglig för att anpassa undervisningen är varken ett hållbart eller ett effektivt användande av resurser (lärarens och elevens tid i klassrummet). Det är i stället viktigt att låta lärare stanna upp och reflektera över tidigare undervisning och dess konsekvenser för att sedan kunna vara nöjd eller göra nödvändiga förändringar i undervisningen.

För att en lärare ska bidra till en hållbar läsutveckling för sina elever behöver läraren använda begrepp, kunskap och metoder från olika teoretiska perspektiv. Till exempel, när en lärare använder ordet avkodning så är det ett kognitivt begrepp och när läraren interagerar med eleven i klassrummet eller tillämpar formativ bedömning så kan det beskrivas som sociokulturella handlingar. När en lärare mäter eller på andra sätt följer elevers utveckling över tid och anpassar sin undervisning till vad som fungerade bättre respektive sämre kan det ses som en beteendeorienterad tillämpning. Ett professionellt förhållningssätt kan beskrivas som förmågan att pragmatiskt 
kombinera olika teoretiska perspektiv i den tidiga läsundervisningens bedömningspraktik. 


\section{Förslag på fortsatt forskning}

Under arbetet med avhandlingen har jag identifierat ett antal kunskapsluckor som inte täcks av min avhandling. Nedan beskrivs dessa som fyra förslag på fortsatt forskning.

Mitt första förslag handlar om att bidra med fördjupade kunskaper om hur lärare använder LegiLexis bedömningsverktyg för att anpassa den tidiga läsundervisningen samt hur de motiverar dessa anpassningar. För att studera detta tillfrågas lärare som använder LegiLexis bedömningsverktyg och ansvarar för läsundervisningen i årskurs F-3. Denna studie ska i likhet med studien i Artikel III bygga på enskilda intervjuer med lärare som arbetar med tidig läsundervisning men ska till skillnad från Artikel III inledas med observationsstudier under pågående läsundervisning. Observationsundersökningarna (deltagande observation) ska tillsammans med en intervjuguide användas som utgångspunkt för intervjuerna för att uppmärksamma och uppmuntra samtal om konkreta händelser och inkludera såväl kognitiva som sociala bedömningsaspekter. Stiftelsen LegiLexi kommer att tillfrågas om en inledande förfrågan om deltagande $\mathrm{i}$ forskningsstudien ställd till lärare som använder LegiLexis verktyg. Resultaten kommer att analyseras med hjälp av tematisk analys (jfr Artikel III)

Det andra förslaget syftar till att bidra med kunskaper om hur effekter av lärarnas användning av LegiLexis bedömningsverktyg kan ses i testresultat över tid (jfr Artikel IV) och elevers självskattning av attityder till skolan och läsning över tid. Varje testtillfälle med LegiLexis testbatteri inleds med tre självskattningsfrågor där eleverna, genom att markera smileyansikten som visar olika känslouttryck, beskriver vad de tycker om att gå i skolan och om att lära sig att läsa. I likhet med Artikel IV görs datainsamlingen via LegiLexis databas och består av avidentifierade testresultat från elever i årskurs F-3 vars lärare använder sig av LegiLexis verktyg i sin undervisning. Denna gång kommer studien att bygga på ett större statistiskt underlag med flera deltagande elever. Resultaten analyseras kvantitativt med variationsanalys.

Ett tredje förslag handlar om en studie där syftet är att bidra med kunskap om yngre elevers upplevelser och erfarenheter av att göra digitala lästest. Studien är ett led i att undersöka hållbara bedömningar från ett elevperspektiv. Urvalet består av elever i årskurs F-3. Data kommer att samlas in med hjälp av intervjuer, enskilda eller i grupp beroende på elevernas egen önskan. För att få tillgång till data vänder jag mig till F-3-lärare som använder digitala test i sin läsundervisning. Förhoppningen är att via lärarna få kontakt med barn och deras vårdnadshavare för att ställa frågan om deltagande $\mathrm{i}$ forskningsstudien. 
Intervjuerna kommer att spelas in med ljud och transkriberas. Resultaten kommer att analyseras med hjälp av narrativ metod.

Det fjärde förslaget handlar om vilka ord och begrepp som kan ses som en gemensam grund och utgångspunkt, jämför lärares professionella yrkesspråk, i kollegiala samtal om läsförmågor och bedömning av dessa. Vilka ord och begrepp kan definieras som gemensamma vad gäller kognitiva respektive sociala bedömningsaspekter? Jag kommer också att intressera mig för ord och begrepp som kan kopplas till professionellt omdöme. Urvalet består av lärare som undervisar $\mathrm{i}$ tidig läsundervisning. Datainsamlingen kommer att göras med hjälp av fokusgruppsintervjuer där lärarna får en eller flera bilder, scenarios, att diskutera och resonera kring (t.ex. en resultattabell med elevers resultat på lästest, en bild som visar tre olika läsutvecklingskurvor eller en bild som visar olika undervisningssituationer). Intervjuerna kommer att spelas in med ljud och transkriberas. Resultaten kommer att analyseras kvantitativt med hjälp av en manual där förekomsten av ord och begrepp räknas och kvalitativt genom narrativ analys. 


\section{Summary}

\section{Introduction}

To be able to read, several different abilities are required and pupils need support by teachers in order to acquire and develop them. In teachers' work of developing pupils' reading, knowledge of reading and of using assessments of reading abilities is necessary. Reading instruction requires that the teacher continuously use this knowledge as a basis and starting point for the pedagogical measures that are used in the classroom. This thesis address how forward-looking assessment can be used and is used by teachers to support pupils' early reading development. Assessment in this thesis is about evaluating pupils' knowledge, abilities and learning needs in relation to early reading instruction. This requires some form of information retrieval by the teacher. The methods for information collection used by the teachers can be of both quantitative and qualitative nature and include cognitive as well as social aspects (cf. McMillan, 2017).

\section{Purpose}

The purpose of the thesis is to contribute with knowledge about how forward-looking assessment can be used and is used by teachers as a basis for pedagogical measures in early reading instruction. By studying the connection between assessment and teaching adaption from different perspectives, I want to contribute with an understanding of how teachers use forward-looking assessments in their reading instruction.

\section{Theory and previous research}

In the thesis, I have adopted a pragmatic approach (Dewey, 2009; Feilzer, 2010) in relation to both theories and methods. The theories used are about reading, forward-looking assessment (formative assessment and Response to intervention) and teachers' professionalism. There are elements of both the socio-cultural and the cognitive and behaviour-oriented perspective in this thesis. They fulfill various functions in the areas of reading and forward-looking assessment.

The Simple View of Reading is a well-established and often used theoretical model that explains reading as the product of word decoding ability and language comprehension (Gough \& Tunmer, 1986). To be able to read and understand a text requires both decoding and language comprehension. Adequate reading instruction means for the teacher to identify the pupils' strengths and difficulties and to systematically and structurally adapt the content and form of the instruction to the pupils' learning needs (Alatalo, 2011: Nordström, 
2018). The thesis uses the term forward-looking assessment (cf. Andersson et al., 2019). The concept comes from the study in Article I where we by comparing two different forward-looking approaches, formative assessment (Wiliam, 2011) and RTI (Fuchs \& Fuchs, 2006; Grigorenko, 2009), identified several key aspects they have in common and others that separated them.

Essential for forward-looking assessments, is that assessments are linked to the pupil's knowledge development with the intention of being used by the teacher to either make adjustments to the instruction, or to provide feedback to the pupil (Fuchs \& Fuchs, 2006; Wiliam, 2011). For teachers who teach in Swedish compulsory school and want to use some form of support in their reading instruction, they have the possibility to use various assessment tools. In Articles II and IV we used a large-scale national assessment tool from the LegiLexi foundation and in Article III we used the locally developed tool Träningslägret. Assessment tools often presuppose that the teacher can interpret the information that the tool provides and can translate this into practical use (Gersten et al., 2020; Herrlin \& Lundberg, 2014). What appears to be a real challenge is to understand what the pupil needs to practice and how the teaching should then be designed (van den Bosch, et al., 2017). Both theoretical competence and practical ability are required to conduct teaching so that it facilitates pupils learning to read despite different conditions (e.g., dyslexia) and differences in prior knowledge (Alatalo, 2011; Høien \& Lundberg, 2013).

How the teacher approaches the work with assessment tools can be linked to teachers' professionalism (Biesta et.al., 2015; Colnerud \& Granström, 2015). Previous studies show, however, that it can take many years to develop the professional competence that characterizes a professional teacher (Colnerud \& Granström, 2015; van den Hurk et al., 2016) and to adapt teaching based on assessment information is considered one of the most advanced skills in the teaching profession (van de Grift, 2007).

\section{Methodological considerations}

The thesis is based on four articles, one theoretical article, two where qualitative method was used and one article where quantitative method was used. The data collection for Article I consisted of literature search using a snowball selection approach. A Venn diagram was used for the analysis and presentation of the results. Data collection for Articles II, III and IV was collected in Swedish compulsory school in connection with teachers and pupils' work with early reading instruction. For Article II, data collection was performed using two focus group interviews (Breen, 2006) with three and five primary school teachers in each group. The teachers were responsible for the early reading instruction and came from different schools spread across Sweden. 
Interview data was analyzed using thematic analysis (Braun \& Clarke, 2006). In Article III, data was collected using 12 individual teacher interviews (Goodson \& Sikes, 2001). The participating teachers were responsible for early reading instruction in various classes within a principal area. The interviews were analyzed using narrative analysis. The data in Article IV consisted of reading test results from the LegiLexi foundation's database. The test results were analyzed using ANOVA.

\section{Results}

In the first article a Venn-diagram (see Figure 3) was used to show the results.

\section{Formative assessment Response to intervention}

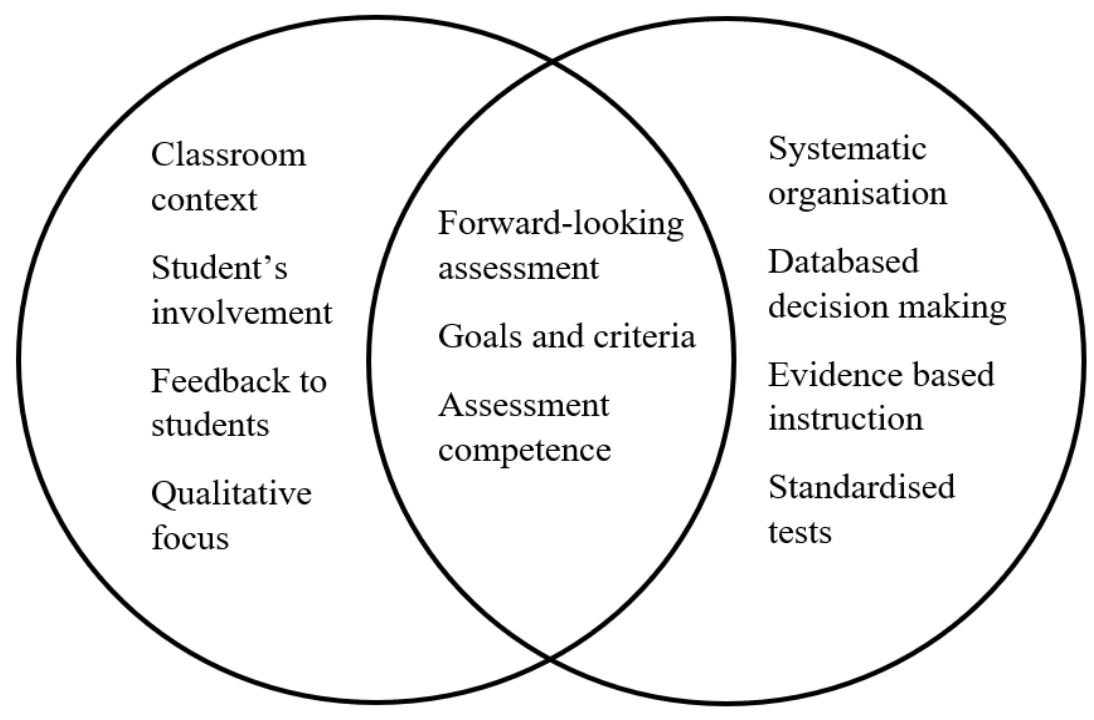

Fig. 3. The Venn diagram illustrates unique key aspects of Formative assessment and Response to intervention and key aspects they have in common (Andersson et al., 2019. p. 112).

In the second article the analysis resulted in three themes: Awareness of student learning; Changes in the teaching organization, but not in terms of individualized content, and Strengthened teaching role, but modest professional growth. The first theme, Awareness of students' learning, showed that teachers had discovered their students' reading development in more detail. They expressed that they now saw the connection between students' reading development and their own teaching. The teacher had become aware of individual needs, including awareness of how different students develop their reading skills. The 
second theme, Changes in teaching, but not regarding individualized content, showed that teachers were aware of how to use differentiated teaching based on the reading profiles and recommendations. This also included that adaptations of the instruction were made in accordance with the students' progression and were used for different temporarily composed student groups. The teachers expressed that they took these considerations seriously, as they emphasized that no student should lag behind in reading development. On the other hand, teaching aimed at individual needs for individual reading components (e.g. word recognition exercises) was not prominent in the results. The final theme, Strengthened teacher role, but modest professional growth, showed that teachers expressed that they had been strengthened in their role as teachers, which affected, for example, communication with parents and with other teachers in the school. In addition, the results showed that teachers had started using the assessment tool and perceived its potential, for example through more developed collaboration with colleagues on how they could improve teaching and how resources could be allocated.

In the third article, the analysis resulted in three narratives that illustrate different types of assessment and adaptations and how these are motivated by the teachers: The first narrative, Listening and challenging, concerns cognitive assessment and adaptation aspects and an adaptation action that is focused on the critical aspects of decoding. The second narrative, To Consider and Simplify, is about the teacher's search for the right adaptation. In the narrative, the teacher describes both cognitive and social assessment aspects. The third narrative, Making independent adaptations, concerns a challenging teaching situation and an adaptation that goes beyond the established form of the project.

In the fourth article, there was a statistically significant main effect of group for all eight tests (all $p s<.001$ ) and the Non-responders group scored lower than the Responders group and Comparison group on all tests (see Table 1). There were also statistically significant main effects of test occasion for all eight tests (all $p s<.05$ ). All three groups improved over time. There were statistically significant interactions between group and test occasions for the tests Phonological awareness, Letter-sound knowledge, Word comprehension, Listening comprehension, Reading comprehension basic, Reading comprehension advanced, Word decoding and Pseudo-word decoding (all $p s<.01$ ). No statistically significant interactions were found for word comprehension and listening comprehension. The Responders group was characterized by initial word decoding problems but showed a significant improvement between the three test sessions, which led them to a higher reading comprehension at the end of year 1 . Their decoding improved most when this skill was the recommended focus area for teaching, but their reading comprehension steadily improved 
when the recommendations were changed. The findings indicate that teachers had used the LegiLexi tool's recommendations to some extent (cf. Figure 1-4). It also seemed that their use contributed to a positive reading development for the 674 pupils who belonged to the Responders group. This group seemed to consist of pupils who learn to read relatively easily, that is, will improve their decoding ability with the help of adequate teaching, which seems to lead to increased reading comprehension. The Non-responders group, whose reading difficulties persisted even at the end of year 1, was more than three times as large as the Responders group. Thus, a large proportion of pupils were considered to be in need for continued decoding instruction.

\section{Discussion and conclusions}

In the thesis, the results are discussed under the headings; Assessments to identify pupils' needs and adapt teaching, followed by; The professional teacher and the support tool, and finally; The pupil as a guiding star.

The results in Article I show that the use of the two forward-looking approaches formative assessment and RTI can offer both opportunities and limitations in assessment practice. One conclusion is that knowledge of different approaches for forward-looking assessment can "[...] facilitate professional growth and judgement and help prevent educational myopia in the classroom" (Andersson et al. 2019, p. 115). In Article I we argue that teachers' knowledge about their pupils' individual learning needs is of critical importance in the assessment practice, not the least from a sustainability perspective. It is not obvious that all pupils are motivated by the request to train a bit more (Perrenoud, 1991). One conclusion is that in some cases, when pupils and teachers are overwhelmed by assessments, a sustainable adaptation in a classroom can mean reducing the number of assessments and focusing on other aspects of teaching. Another conclusion is that what actually promotes pupils' learning and well-being should be the most important issue when assessments are used, regardless of type. Reflecting on the consequences of each assessment is at the heart of a pragmatic view of forward-looking assessment.

In the thesis, as well as in previous research, the importance of early identification and adaption to different learning needs in order to minimise the risk that any pupil is left behind is stressed (Catts et.al., 2016; Snow, 1998).

Previous studies show that it can take several years to develop teachers' professional competence (Colnerud \& Granström, 2015; van den Hurk et.al., 2016). Support in teachers' work with analysis, so that assessment information can be used to adapt instruction, is an aspect that positively affects the growth of the teacher (van den Hurk et.al., 2016). The results in Article II show that LegiLexi's assessment tool 
helped teachers to observe their pupils' reading development in more detail and received support in linking it to their own teaching. The tool also contributed to a stronger teacher role, but a modest professional growth. One conclusion is that in order to be able to make full use of all available assessment information and for teachers' opportunities and ability to support different pupils' individual needs, further implementation of the tool is required.

Results in Article III show that a variety of both cognitive and social assessment aspects are taken into account by the teachers when they adapt the decoding teaching within the Training camp (Träningslägret) (cf. Heritage, 2013; McMillan, 2017). One conclusion is that the social assessments made by the teachers were given decisive importance for the pupil's decoding training. The results highlights the need for a professional space for action for the teachers. To acquire this places demands on teachers' subject knowledge and didactic ability, but also on self-reflection, judgment and a professional, ethical approach. One conclusion is that these competencies are important because they can contribute to the teacher developing a balance where the pupil's needs are taken into account in the short and long term and balance between internal and external expectations in their assessment practice. In my opinion, a professional approach can be described as the ability to pragmatically combine different theoretical perspectives in the assessment practice of early reading instruction. Decoding means being able to connect the letter symbol with the language sound (Gustafson et al., 2007; Høien, \& Lundberg, 2013).

The pupils' decoding ability develops over time. The goal is to achieve automatized decoding as it can be seen as a basis and prerequisite for reading comprehension (Høien, \& Lundberg, 2013; Myrberg, 2001). In line with previous research (e.g. Adams, 1990; Ehri, 2020), the results in Article IV show that it is mainly word decoding that signals critical differences in early reading development.

The findings in Article IV showed that the Responders Group (pupils who have an easy time learning to read) was characterized by initial word decoding problems but showed a significant improvement between the three test sessions, which led them to a higher reading comprehension at the end of year 1 . Respondents' decoding improved most when this skill was the recommended focus area for teaching, but their reading comprehension improved steadily even when the recommendations changed. The group of Non-responders (pupils who have difficulty learning to read), whose reading difficulties persisted also at the end of year 1 , was more than three times as large as the Responders group. One conclusion is that a large proportion of pupils in year 1 still need decoding training even at the end of year 1 . Assessment tools used during the first years of school in reading instruction need to provide teachers with clear and recurring information about the pupil's ability to decode words. The question of 
how these pupils' reading development should best be supported remains to be answered.

In the thesis, I argue that teachers need to pay attention to specific conditions and organizing the assessment practice so that a mutual and sustainable exchange occurs between the teacher, the pupil and the assessment tool. In the thesis, the concept of sustainability is used and then refers to the assessment practice placed in a larger context where other aspects of reading instruction can be quite important. Reading instruction is not all about assessment, but it cannot be denied that it is of central importance. What the teacher does is important regardless of the choice of approach, method or assessment tool. The thesis contributes with knowledge by highlighting the importance of following pupils over time and using different types of assessment information to adapt the instruction to the individual. The pupils progress is the result of how effective reading instruction has been, which can be revealed by test results, but for this development to be sustainable, the pupil's motivation and well-being must also be taken into account.

Keywords: Early reading instruction, decoding, forward-looking assessment, assessment aspects, Response to intervention (RTI), formative assessment, teachers' professionalism. 


\section{Referenser}

Aaron, P. G. (1997). The impending demise of the discrepancy formula. Review of Educational Research, 67(4), 461-502.

Adams, M. J. (1990). Beginning to read: Thinking and learning. About Print.

Alatalo, T. (2011). Skicklig läs-och skrivundervisning i åk 1-3: Om lärares möjligheter och hinder (Doktorsavhandling). Göteborgs universitet. ISBN: 978-91-7346-709-4.URL:

Andersson, U. B. (2021). Hur använder lärare bedömning i tidig läsundervisning? I A. Hirsh, \& C, Lundahl. (red.). Hållbar bedömning, bildning, välbefinnande och utveckling $i$ skolans bedömningsarbete. s. 67-84. Natur \& Kultur.

Andersson, U. B., \& Löfgren, H. (under utgivning). Bedömningar för anpassning i tidig läsundervisning: Lärares erfarenheter av att utveckla elevers avkodningsförmåga. Pedagogisk forskning $i$ Sverige.

Andersson, U. B., Löfgren, H., \& Gustafson, S. (2019). Forwardlooking assessments that support students' learning: A comparative analysis of two approaches. Studies in Educational Evaluation, 60, 109-116.

Applebee, A. N., Langer, J. A., Nystrand, M., \& Gamoran, A. (2003). Discussion-based approaches to developing understanding: Classroom instruction and student performance in middle and high school English. American Educational Research Journal, 40(3), $685-730$.

Baines, E., Rubie-Davies, C., \& Blatchford, P. (2009). Improving pupil group work interaction and dialogue in primary classrooms: results from a year-long intervention study. Cambridge Journal of Education, 39(1), 95-117. 
Baker, L., \& Wigfield, A. (1999). Dimensions of children's motivation for reading and their relations to reading activity and reading achievement. Reading Research Quarterly, 34(4), 452-477.

Bennett, R. E. (2011). Formative assessment: A critical review. Assessment in Education: Principles Policy and Practice, 18(1), 525.

Berkeley, S., Bender, W. N., Gregg Peaster, L., \& Saunders, L. (2009). Implementation of Response to intervention: A snapshot of progress. Journal of Learning Disabilities, 42(1), 85-95.

Biesta, G., Priestley, M., \& Robinson, S. (2015). The role of beliefs in teacher agency. Teachers and Teaching, 21(6), 624-640.

Birenbaum, M., Kimron, H., \& Shilton, H. (2011). Nested contexts that shape assessment for learning: School-based professional learning community and classroom culture. Studies in Educational Evaluation, 37, 35-48.

Black, P. (2015). Formative assessment-an optimistic but incomplete vision. Assessment in Education: Principles, Policy \& Practice, 22(1), 161-177.

Black, P. J., Harrison, C., Lee, C., Marshall, B., \& Wiliam, D. (2004). Working inside the black box: Assessment for learning in the classroom. Phi Delta Kappan, 86(1), 9-21.

Black, P. \& William, D. (1998). Assessment and classroom learning. Assessment in Education: Principles, Policy \& Practice, 5(1), 7-74.

Black, P., \& Wiliam, D. (2009). Developing the theory of formative assessment. Educational Assessment, Evaluation and Accountability, 21(1), 5.

Black, P., \& Wiliam, D. (2018). Classroom assessment and pedagogy, Assessment in Education: Principles, Policy \& Practice, 25(6), 551575.

Blanc, S., Christman, J. B., Liu, R., Mitchell, C., Travers, E., \& Bulkley, K. E. (2010). Learning to learn from data: Benchmarks and 
instructional communities. Peabody Journal of Education, 85(2), 205-225.

Boud, D., \& Soler, R. (2016). Sustainable assessment revisited. Assessment \& Evaluation in Higher Education, 41(3), 400-413.

van den Bosch, R. M., Espin, C. A., Chung, S., \& Saab, N. (2017). Data-based decision making: Teachers' comprehension ofcurriculum-based measurement progress monitoring graphs. Learning Disabilities Research and Practice, 32(1), 46-60.

Braun, V., \& Clarke, V. (2006). Using thematic analysis in psychology. Qualitative Research in Psychology, 3(2), 77-101.

Breen, R. L. (2006). A practical guide to focus-group research. Journal of Geography in Higher Education, 30(3), 463-475.

Burman, A. (2014). Den reflekterade erfarenheten: John Dewey om demokrati, utbildning och tänkande. Södertörns högskola. Tillgänglig: sh.diva-portal.org/smash/get/diva2:745733/ FULLTEXT01. pdf Hämtad: 20160211.

Cain, K. (2010). Reading development and difficulties. BPS Blackwell/John Wiley.

Carlgren, I., Forsberg, E. \& Lindberg, V. (2009). Perspektiv på den svenska skolans kunskapsdiskussion (Rapport 7/2009). Stockholms universitetsförlag \& Centrum för studier av skolans kunskapsinnehåll.

Castles, A., Rastle, K., \& Nation, K. (2018). Ending the reading wars: Reading acquisition from novice to expert. Psychological Science in the Public Interest, 19, 5-51.

Catts, H. W., Adlof, S. M., \& Weismer, S. E. (2006). Language deficits in poor comprehenders: A case for the simple view of reading. Journal of Speech, Language, and Hearing Research (49), 278-293. 
Catts, H. W., Hogan, T. P., \& Fey, M. E. (2003). Subgrouping poor readers on the basis of individual differences in reading-related abilities. Journal of Learning Disabilities, 36(2), 151-164.

Catts, H. W., Nielsen, D. C., Bridges, M. S., \& Liu, Y. S. (2016). Early identification of reading comprehension difficulties. Journal of learning disabilities, 49(5), 451-465.

Creswell, J. W., \& Creswell, J. D. (2017). Research design: Qualitative, quantitative, and mixed methods approaches. Sage publications.

Creswell, J. W., \& Miller, D. (2000). Determining validity in qualitative inquiry. The Police Journal, 39(3), 125-130.

Creswell, J. W., \& Poth, C. N. (2017). Qualitative inquiry and research design: Choosing among five approaches. Sage publications.

Colnerud, G., \& Granström, K. (2015). Respekt för lärarprofessionen: om lärares yrkesspråk och yrkesetik. Liber.

Dewey, J. (2009). Demokrati och utbildning. Diadalos AB.

Edyburn, D. L. (2015). Expanding the use of assistive technology while mindful of the need to understand efficacy', efficacy of assistive technology interventions. Advances in Special Education Technology, Volume 1 (pp. 1-12). Emerald Group Publishing Limited.

Ehri, L. C. (2020). The science of learning to read words: A case for systematic phonics instruction. Reading Research Quarterly, 55, 45-60.

Ehri, L. C., Nunes, S. R., Willows, D. M., Schuster, B. V., YaghoubZadeh, Z., \& Shanahan, T. (2001). Phonemic awareness instruction helps children learn to read: Evidence from the National Reading Panel's meta-analysis. Reading Research Quarterly, 36(3), 250287. 
Elwér, Å. (2014). Early predictors of reading comprehension difficulties (Doctoral dissertation, Linköping). University Electronic Press.

Feilzer, Y. M. (2010). Doing mixed methods research pragmatically: Implications for the rediscovery of pragmatism as a research paradigm. Journal of Mixed Methods Research, 4(1), 6-16.

Florit, E., \& Cain, K. (2011). The simple view of reading: Is it valid for different types of alphabetic orthographies? Educational Psychology Review, 23(4), 553-576.

Fuchs, D., \& Fuchs, L. S. (2006). Introduction to Response to intervention: What, why, and how valid is it? Reading Research Quarterly, 41(1), 93-99.

Fuchs, D., \& Fuchs, L. S. (2009). Responsiveness to intervention: Multilevel assessment and instruction as early intervention and disability identification. The Reading Teacher, 63(3), 250-252.

Fuchs, D., Fuchs, L. S., \& Compton, D. L. (2012). Smart RTI: A nextgeneration approach to multilevel prevention. Exceptional Children, 78(3), 263-279.

Fuchs, D., \& Fuchs, L. S. (2017). Critique of the national evaluation of Response to intervention: A case for simpler frameworks. Exceptional Children, 83(3), 255-268.

Fälth, L., Gustafson, S., Kugelberg, E., \& Nordström, T. (2017). LegiLexis formativa bedömningsverktyg-Testmanual.

Fälth, L., \& Svensson, I. (2015). An app as 'reading glasses'-A study of the interaction between individual and assistive technology for students with a dyslexic profile. International Journal of Teaching and Education, 3(1), 1-12.

Gardner, J. (Ed.). (2012). Assessment and learning. Sage.

Gersten, R., Haymond, K., Newman-Gonchar, R., Dimino, J., \& Jayanthi, M. (2020) Meta-Analysis of the Impact of Reading 
Interventions for Students in the Primary Grades, Journal of Research on Educational Effectiveness, 13(2), 401-427.

Goodson, I. F., \& Sikes, P. J. (2001). Life history research in educational settings: Learning from lives. Open University Press. ISBN 0335207146.

Gough, P. B. \& Tunmer, W. E. (1986). Decoding, Reading, and Reading Disability. Remedial \& Special Education 7, 6-10.

Grigorenko, E. L. (2009). Dynamic assessment and response to intervention: Two sides of one coin. Journal of Learning Disabilities, 42, 111-132.

van de Grift, W. (2007). Quality of teaching in four European countries: A review of the literature and application of an assessment instrument. Educational Research, 49(2), 127-152.

Gustafson, S., Ferreira, J., \& Rönnberg, J. (2007). Phonological or orthographic training for children with phonological or orthographic decoding deficits. Dyslexia, 13, 211-229.

Gustafson, S., Fälth, L., Svensson, I., Tjus, T., \& Heimann, M. (2011). Effects of three interventions on the reading skills of children with reading disabilities in grade 2. Journal of Learning disabilities, 44(2), 123-135.

Gustafson, S., Nordström, T., Andersson, U. B., Fälth, L., \& Ingvar, M. (2019). Effects of a formative assessment system on early reading development. Education, 140(1), 17-27.

Gustafson, S., Samuelsson, C., Johansson, E. \& Wallmann, J. (2013). How simple is the simple view of reading? Scandinavian Journal of Educational Research, 57(3), 292-308.

Gustafson, S., Svensson, I., \& Fälth, L. (2014). Response to intervention and dynamic assessment: implementing systematic, dynamic and individualised interventions in primary school. International Journal of Disability, Development and Education, 61(1), 27-43. 
Hartman, S. G. (2012). Det pedagogiska kulturarvet. Natur och kultur. Hattie, J. (2008). Visible learning: A synthesis of over 800 metaanalyses relating to achievement. Routledge.

Heritage, M. (2013). Gathering evidence of student understanding. Sage handbook of research on classroom assessment, 179-195.

Herrlin, K., \& Lundberg, I. (2014). God läsutveckling: Kartläggning och övningar. Natur \& Kultur.

Heward, W. L. \& Cooper, J. O. (1992). Radical behaviourism: A productive and needed philosophy for education. Journal of Behavioral Education, 2(4), 345-365.

Hirsh, Å. (2017). Perspektiv på skolans pedagogiska dokumentationden skriftliga individuella utvecklingsplanens roll och relation till annan dokumentation. Skolverket.

Hirsh, Å. (2020). When assessment is a constant companion: students' experiences of instruction in an era of intensified assessment focus. Nordic Journal of Studies in Educational Policy, 6(2), 89102.

Hirsh, Å., \& Lindberg, V. (2015). Formativ bedömning på 2000-taleten översikt av svensk och internationell forskning. Vetenskapsrådets rapportserie.

Hirsh, Å., \& Lundahl, C (red.). (2021). Hållbar bedömning, bildning, välbefinnande och utveckling $i$ skolans bedömningsarbete. Natur \& Kultur.

Hirsh, Å., Nilholm, C., Roman, H., Forsberg, E., \& Sundberg, D. (2020). Reviews of teaching methods-which fundamental issues are identified?. Education Inquiry, 1-20.

Hoover, W. A., \& Gough, P. B. (1990). The simple view of reading. Reading and Writing, 2(2), 127-160.

Howe, C., \& Abedin, M. (2013) Classroom dialogue: a systematic review across four decades of research. Cambridge Journal of Education, 43(3), 325-356. 
van den Hurk, H. T. G., Houtveen, A. A. M., \& van de Grift, W. J. C. M. (2016). Fostering effective teaching behavior through the use of data-feedback. Teaching and Teacher Education, 60, 444-451.

Høien, T., \& Lundberg, I. (2013). Dyslexi, från teori till praktik (2:a uppl.). Natur och Kultur.

Jacobson, C., Björn, M., \& Svensson, I. (2009). Dyslexi och kompensatoriska/alternativa hjälpmedel. I Samuelsson m.fl. Dyslexi och andra svårigheter med skriftspråket, 295-321.

Johnson, R. B., \& Onwuegbuzie, A. J. (2004). Mixed methods research: A research paradigm whose time has come. Educational Researcher, 33(7), 14-26.

Jonsson, A., Lundahl, C., \& Holmgren, A. (2015) Evaluating a largescale implementation of Assessment for Learning in Sweden. Assessment in Education: Principles, Policy \& Practice, 22(1), 104-121.

Keenan, J. M., Betjemann, R. S., \& Olson, R. K. (2008). Reading comprehension tests vary in the skills they assess: Differential dependence on decoding and oral comprehension. Scientific Studies of Reading, 12(3), 281-300.

Keenan, J. \& Meenan, C. E. (2014). Test differences in diagnosing reading comprehension deficits. Journal of Learning Disabilities, 47,125-135.

Korp, H. (2011). Kunskapsbedömning: Vad, hur, varför?: kunskapsöversikt. Skolverket.

Krueger, R. (2000). Focus groups: A practical guide for applied research. Sage.

Labov, William., \& Waletzky, Joshua. (1967/1997). Narrative analysis: Oral versions of personal experience. Journal of Narrative and Life History, 7(1-4). 
Lai, M. K., \& McNaughton, S. (2016). The impact of data use professional development on student achievement. Teaching and Teacher Education, 60, 434-443.

Lam, E. A., \& McMaster, K. L. (2014). Predictors of responsiveness to early literacy intervention: A 10-year update. Learning Disability Quarterly, 37(3), 134-147.

Larsson, S. (2009). A pluralist view of generalization in qualitative research. International journal of research \& method in education, 32(1), 25-38.

Lauvås, P. \& Jönsson, A. (2019). Ren formativ bedömning. Studentlitteratur.

Leahy, S., \& Wiliam, D. (2012). From teachers to schools: Scaling up professional development for formative assessment. Assessment and Learning, 2, 49-71.

LegiLexi (u.å.). En liten stiftlese med stora mål. Hämtad: 210423 https://legilexi.org/om-oss/

Levin, H. M. (2013). The utility and need for incorporating noncognitive skills into large-scale educational assessments. In The role of international large-scale assessments: Perspectives from technology, economy, and educational research (pp. 67-86). Springer.

Lonigan, C. J., Burgess, S. R., \& Schatschneider, C. (2018). Examining the simple view of reading with elementary school children: Still simple after all these years. Remedial and Special Education, 39(5), 260-273.

Lundahl, C. (2011). Bedömning för lärande. Nordstedts.

Lundberg, I., Frost, J. \& Petersen O-P. (1988). Effects of an extensive program for stimulating phonological awareness in preschool children. Reading Research Quarterly, 23, 264-293. 
McMillan, James. H. (2017). Classroom assessment: Principles and practice that enhance student learning and motivation. Pearson. ISBN 978-0-13-452330-9.

Means, B., Chen, E., Debarger, A., \& Padilla, C. (2011). Teachers' ability to use data to inform instruction: Challenges and supports. Office of Planning, Evaluation and Policy Development, US Department of Education 1-122.

Mercer, N., Dawes, L., Wegerif, R., \& Sams, C. (2004). Reasoning as a scientist: Ways of helping children to use language to learn science. British Educational Research Journal, 30(3), 359-377.

Mishler, Elliot. G. (1999). Storylines. Craftartists' Narratives of Identity. Georgia: Harvard University Press (s. 1-52).

Moats, L. (2009). Knowledge foundations for teaching reading and spelling. Reading and Writing, 22(4), 379-399.

Myrberg, M. (2001). Att förebygga och möta läs-och skrivsvårigheter: en forskningsöversikt på uppdrag av Skolverket. Skolverket.

Nordström, T. (2018). Measures that matter: Facilitating literacy through targeted instruction and assistive technology (Doctoral dissertation). Linnaeus University Press.

Nordström, T., Andersson, U. B., Fälth, L., \& Gustafson, S. (2019). Teacher inquiry of using assessments and recommendations in teaching early reading. Studies in Educational Evaluation, 63, 9-16.

Oakhill, J., \& Cain, K. (2012). The precursors of reading ability in young readers: Evidence from a four-year longitudinal study. Scientific Studies of Reading, 16(2), 37-41.

Oakhill, J., Cain, K., \& Elbro, C. (2019). Reading comprehension and reading comprehension difficulties. In Reading Development and Difficulties (pp. 83-115). Springer.

Perez Prieto, H. (2006). Historien om räven och andra berättelser. Om klasskamrater och skolan på en liten ort - ur ett skol-och 
livsberättelseperspektiv. Karlstad University Studies 2006 (52) (s. 94).

Perrenoud, P. (1991). Towards a pragmatic approach to formative evaluation. In P. Weston (Ed.), Assessment of pupils' achievement: Motivation and school success pp. 79-10. Swets and Zeitlinger.

Piaget, J. (1964). PART 1 Cognitive Development in Children: Piaget Development and Learning. Journal of Research in Science Teaching, 2, 176-186.

Pope, J., Annandale, D., \& Morrison-Saunders, A. (2004). Conceptualising sustainability assessment. Environmental impact assessment review, 24(6), 595-616.

Ramus, F. (2004). The neural basis of reading acquisition. The cognitive neurosciences, 815-824. In press in M. S. Gazzaniga (Ed.), The New Cognitive Neurosciences (3rd ed.).

Rayner, K., Foorman, B. R., Perfetti, C. A., Pesetsky, D., \& Seidenberg, M. S. (2001). How psychological science informs the teaching of reading. Psychological Science in the Public Interest, 2(2), 31-74.

Sadler, D. R. (1989). Formative assessment and the design of instructional systems. Instructional Science, 18(2), 119-144.

SBU. Dyslexi hos barn och ungdomar - tester och insatser. En systematisk litteraturöversikt. Statens beredning för medicinsk utvärdering (SBU); 2014. SBU-rapport nr: 225. ISBN 978-9185413-66-9.

Scriven, M. (1967). The methodology of evaluation. In R. Tyler, R. Gagne, and M. Scriven (Eds.), Perspectives on curriculum evaluation (AERA monograph series - curriculum evaluation, pp.112). Rand McNally.

Schildkamp, K., \& Kuiper, W. (2010). Data-informed curriculum reform: Which data, what purposes, and promoting and hindering factors. Teaching and Teacher Education, 26(3), 482-496.

Schuele, C. M., \& Boudreau, D. (2008). Phonological awareness intervention: Beyond the basics. Language, speech, and hearing services in schools.

Skollag. (2010:800). Utbildningsdepartementet.

Skolverket. (u.å.). Bedömningsstöd i svenska och svenska som andraspråk. Hämtat: 210423. https://www.skolverket.se /undervisning/grundskolan/bedomning-i- 
grundskolan/bedomningsstod-i-amnen-i-grundskolan/ bedomningsstod-svenska-svenska-som-andrasprak-grundskolan

Skolverket. (2011). Kunskapsbedömning i skolan- Praxis, begrepp, problem och möjligheter. Skolverket.

Skolverket. (2019). Läroplanför grundskolan, förskoleklassen och fritidshemmet: Reviderad 2019. Skolverket.

Snow. (1998). Preventing reading difficulties in young children. National Research Council.

Snowling, M. J. (2013). Early identification and interventions for dyslexia: a contemporary view. Journal of Research in Special Educational Needs, 13(1), 7-14.

Snow, C. E., \& Juel, C. (2005). Teaching children to read: What do we know about how to do it? In Snowling, M.J and Hulme, C. The Science of Reading: A Handbook.p.397-412

Stanovich, K. E., Nathan, R. G., \& Vala-Rossi, M. (1986). Developmental changes in the cognitive correlates of reading ability and the developmental lag hypothesis. Reading Research Quarterly, 267-283.

Taras, M. (2009). Summative assessment: The missing link for formative assessment. Journal of Further and Higher Education, 33(1), 57-69.

Taube, K. (2013). Läsning och självförtroende: Psykologiska teorier, empiriska undersökningar och pedagogiska konsekvenser. (5.uppl.). Studentlitteratur AB.

Taube, K., Fredriksson, U., \& Olofsson, А̊. (2015). Kunskapsöversikt om läs-och skrivundervisning för yngre elever (Vetenskapsrådets delrapport). Vetenskapsrådet.

Tunmer, W., \& Greaney, K. (2010). Defining dyslexia. Journal of Learning Disabilities, 43, 229-243.

Vaughn, S., \& Fuchs, L. S. (2003). Redefining learning disabilities as inadequate response to instruction: The promise and potential 
problems. Learning Disabilities Research and Practice, 18(3), 137146.

Wayman, M., Wallace, T., Wiley, H. I., Tichá, R., \& Espin, C. A. (2007). Literature synthesis on curriculum-based measurement in reading. The Journal of Special Education, 41(2), 85-120

Vellutino, F. R., Tunmer, W. E., Jaccard, J. J., \& Chen, R. (2007). Components of reading ability: Multivariate evidence for a convergent skills model of reading development. Scientific Studies of Reading, 11, 3-32.

Vetenskapsrådet. (2017). God forskningssed.

Wiliam, D. (2011). Embedded formative assessment. Solution Tree Press.

Wolff, U. (2011). Effects of a randomised reading intervention study: An application of structural equation modelling. Dyslexia, 17(4), $295-311$.

Woolley, G. (2011). Reading Comprehension Assisting Children with Learning Difficulties p. 15-35. Springer.

Vygotsky L. S. (1978). Sociokulturell teori. Sinne i samhället, 6, 5258.

Zeuch, N., Förster, N., \& Souvignier, E. (2017). Assessing teachers' competencies to read and interpret graphs from learning progress assessment: Results from tests and interviews. Learning Disabilities Research and Practice, 32(1), 61-70. 


\section{Artiklar}

De till denna avhandling tillhörande artiklarna har tagits bort av upphovsrättsliga skäl. För mer information gå till:

http://urn.kb.se/resolve?urn=urn:nbn:se:liu:diva-175577 


\section{UTBILDNINGSVETENSKAP}

Linköping Studies in Behavioural Science No. 229, 2021

Department of Behavioural Sciences and Learning

Linköping University

SE-581 83 Linköping, Sweden

wWw.liu.se 